\title{
Sources of carbonaceous aerosol in the Amazon basin
}

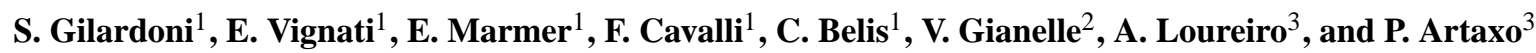 \\ ${ }^{1}$ Joint Research Centre, Institute for Environment and Sustainability, Climate Change Unit, Ispra, Italy \\ ${ }^{2}$ ARPA Lombardia, via F. Restelli 3/1, Milan, Italy \\ ${ }^{3}$ Instituto de Fisica, Universidade de São Paolo, Rua do Matao, Sao Paulo, Brazil
}

Received: 6 October 2010 - Published in Atmos. Chem. Phys. Discuss.: 9 December 2010

Revised: 14 March 2011 - Accepted: 15 March 2011 - Published: 24 March 2011

\begin{abstract}
The quantification of sources of carbonaceous aerosol is important to understand their atmospheric concentrations and regulating processes and to study possible effects on climate and air quality, in addition to develop mitigation strategies.

In the framework of the European Integrated Project on Aerosol Cloud Climate Interactions (EUCAARI) fine $\left(D_{\mathrm{p}}<\right.$ $2.5 \mu \mathrm{m})$ and coarse $\left(2.5 \mu \mathrm{m}<D_{\mathrm{p}}<10 \mu \mathrm{m}\right)$ aerosol particles were sampled from February to June (wet season) and from August to September (dry season) 2008 in the central Amazon basin. The mass of fine particles averaged $2.4 \mu \mathrm{g} \mathrm{m}^{-3}$ during the wet season and $4.2 \mu \mathrm{g} \mathrm{m}^{-3}$ during the dry season. The average coarse aerosol mass concentration during wet and dry periods was 7.9 and $7.6 \mu \mathrm{g} \mathrm{m}^{-3}$, respectively. The overall chemical composition of fine and coarse mass did not show any seasonality with the largest fraction of fine and coarse aerosol mass explained by organic carbon (OC); the average $\mathrm{OC}$ to mass ratio was 0.4 and 0.6 in fine and coarse aerosol modes, respectively. The mass absorbing cross section of soot was determined by comparison of elemental carbon and light absorption coefficient measurements and it was equal to $4.7 \mathrm{~m}^{2} \mathrm{~g}^{-1}$ at $637 \mathrm{~nm}$. Carbon aerosol sources were identified by Positive Matrix Factorization (PMF) analysis of thermograms: $44 \%$ of fine total carbon mass was assigned to biomass burning, $43 \%$ to secondary organic aerosol (SOA), and $13 \%$ to volatile species that are difficult to apportion. In the coarse mode, primary biogenic aerosol particles (PBAP) dominated the carbonaceous aerosol mass. The results confirmed the importance of PBAP in forested areas.

The source apportionment results were employed to evaluate the ability of global chemistry transport models to simulate carbonaceous aerosol sources in a regional tropical back-
\end{abstract}

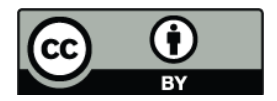

Correspondence to: E. Vignati (elisabetta.vignati@jrc.ec.europa.eu) ground site. The comparison showed an overestimation of elemental carbon (EC) by the TM5 model during the dry season and OC both during the dry and wet periods. The overestimation was likely due to the overestimation of biomass burning emission inventories and SOA production over tropical areas.

\section{Introduction}

Carbonaceous aerosols play a major role in aerosol climate impact, through a direct and an indirect effect on incoming solar radiation. Carbonaceous aerosols are treated here as composed by organic carbon (OC) and a strongly light-absorbing carbonaceous component that, consistently with the IPCC report (IPCC, 2001) we will call soot. The acronym OC identifies carbon that composes organic molecular species and polymeric compounds; their contribution to aerosol mass is defined as organic mass (OM), which includes also the contribution of hydrogen, oxygen and other elements associated to carbon in organic molecules. Soot has a graphite-like structure and is generated by incomplete combustion of organic material; this component of ambient aerosol is also referred to as elemental carbon (EC) and equivalent black carbon (EBC), although we should keep in mind that the use of one of these terms implies a different empirical definition (Bond and Bergstrom, 2006). EC is measured by thermal-optical techniques and corresponds to the more refractive component of carbonaceous aerosols. EBC definition is based on aerosol optical properties and it is quantified by the intensity of light attenuation.

The direct effect of carbonaceous aerosols on climate is due to scattering and absorption of sunlight, while the indirect effect is due to the aerosol ability to affect cloud properties and cloud lifetime. The influence of atmospheric

Published by Copernicus Publications on behalf of the European Geosciences Union. 
species on climate is quantified by their radiative forcing. The total aerosol radiative forcing is estimated to be $-0.5 \pm 0.4 \mathrm{~W} \mathrm{~m}^{-2}$, with soot having a contribution equal to $+0.2 \pm 0.1 \mathrm{~W} \mathrm{~m}^{-2}$ and $\mathrm{OC}$ equal to $-0.3 \pm 0.1 \mathrm{~W} \mathrm{~m}^{-2}$ (IPCC, 2007; Andreae and Crutzen, 1997; Liao et al., 2004). The large numerical uncertainties are caused by the limited understanding of chemical and physical properties of carbonaceous particles and by the difficulties to model carbon particles on a global scale (Goldstein and Galbally, 2007; Fuzzi et al., 2006). The inaccuracy of carbonaceous aerosol modeling is mainly due to the uncertainties of anthropogenic and natural emission inventories, and to the description of secondary organic aerosol; the large change in land use that recently affected tropical forested areas compromises even more the inventory accuracy (Kanakidou et al., 2005).

Our interest in the Amazon area is due to the large contribution of South American continent to the global aerosol carbon budget. South America is responsible for $16 \%$ of the global soot emissions and $22 \%$ of the primary OC emissions from open burning and contained combustion (Bond et al., 2004). The largest contribution comes from the open burning that is localized in the northern part of the continent, including the Amazon area (Streets et al., 2004). In addition to primary carbonaceous aerosols, the Amazon contributes significantly to secondary OC through oxidation of volatile organic compounds (VOC) emitted by forest vegetation. The Amazon basin is an important source of carbonaceous aerosol also on the global scale. In fact this area is characterized by an intense convective activity that lifts air masses towards high altitudes and allows them to be transported to long distances (Andreae et al., 2001; Staudt et al., 2001), increasing the relevance of the Amazon area as source of gaseous aerosol precursors on a global scale.

Carbonaceous aerosol sources in the Amazon basin follow a marked seasonality (Martin et al., 2010). During the wet season carbonaceous aerosol mass is dominated by primary biological aerosol particles (PBAP) and secondary organic aerosol (SOA) (Graham et al., 2003; Decesari et al., 2006; Prenni et al., 2009; Chen et al., 2009). PBAP found in the Amazon forest include viruses, bacteria, fungi, spores, pollen, and plant debris; their size ranges from few nanometers to millimeters (Elbert et al., 2007; Graham et al., 2003). SOA represents a significant faction of fine aerosol mass. SOA is formed by nucleation and condensation of oxidation products of biogenic VOCs, such as isoprene and terpenes. In addition, particle-phase reactions (Surratt et al., 2010) and aqueous phase oxidation of organic precursors (Lim et al., 2010) from biogenic or anthropogenic sources, including biomass burning, could contribute to SOA formation in the Amazon region. During the dry season (JuneNovember) the weather conditions facilitate ignition and diffusion of fires, increasing the contribution of pyrogenic particles to fine carbonaceous aerosol (Guyon et al., 2003; Decesari et al., 2006).
The Amazon basin aerosols have been studied during the past decades; most of the literature data reports concentration of elements (by PIXE analysis) and explain a limited fraction of the aerosol mass (Artaxo et al., 1990, 1994; Echalar et al., 1998; Guyon et al., 2003, 2004). Only a small number of experiments included measurements of carbonaceous aerosol (Artaxo et al., 2002; Decesari et al., 2006; Graham et al., 2003; Soto-Garcia et al., 2010). These experiments were carried out between 1999 and 2002, when the Amazon deforestation rate was about 2 times larger than now. The decrease of deforestation rate together with rapid economic growth of South American countries require an up-dated investigation of aerosol properties and sources.

The work presented here is part of the European Integrated Project on Aerosol Cloud Climate Interactions (EUCAARI) (Kulmala et al., 2009), which aims at reducing the uncertainties of aerosol particle effects on climate. The first part of the EUCAARI project in Amazonia overlapped with the Amazonian Aerosol Characterization Experiment 2008 (AMAZE08) (Gunthe et al., 2009; Martin et al., 2010; Pöschl et al., 2010). The goal of this paper is to gain insights of properties and sources of carbonaceous aerosol in an area that contributes substantially to the global budget of carbonaceous particles. Chemical composition of fine and coarse aerosols during 2008 wet and dry season are presented. Differently from most of the previous studies, the chemical measurements are able to describe completely the aerosol mass. Carbonaceous aerosols are characterized as OC and soot and their thermal-optical properties are used to identify carbon sources. OC and soot data are then compared to model results to identify the weaknesses of carbon modeling in a regional background forested area, constraining the contribution of biogenic and pyrogenic particles, to eventually reduce the uncertainty in aerosol global forcing.

\section{Measurement description}

\subsection{Aerosol sampling}

The sampling site is a mostly pristine rain forest site located about $60 \mathrm{~km}$ north-northwest of Manaus (Fig. 1) in the Reserva Biologica do Cuieiras in Brazil $\left(2.595^{\circ} \mathrm{S}\right.$, $60.209^{\circ} \mathrm{W}, 110 \mathrm{~m}$ above sea level, see Fig. 1). The site is downwind of pristine forest for more than $2000 \mathrm{~km}$, since the prevailing winds are from the northeast, bringing Atlantic Ocean air masses over $2000 \mathrm{~km}$ of pristine forest (Fig. 2) (Ahlm et al., 2009; Martin et al., 2010). Occasionally some air masses from the south pass over the urban area of Manaus, and reach the site but with very little effects over the aerosol mass and composition over long term measurements.

Aerosol sampling was performed under the forest canopy from 10 February to 5 June and from 17 August to 19 September 2008. The first part of the sampling campaign (February-June) corresponded to the Amazonian wet season, 


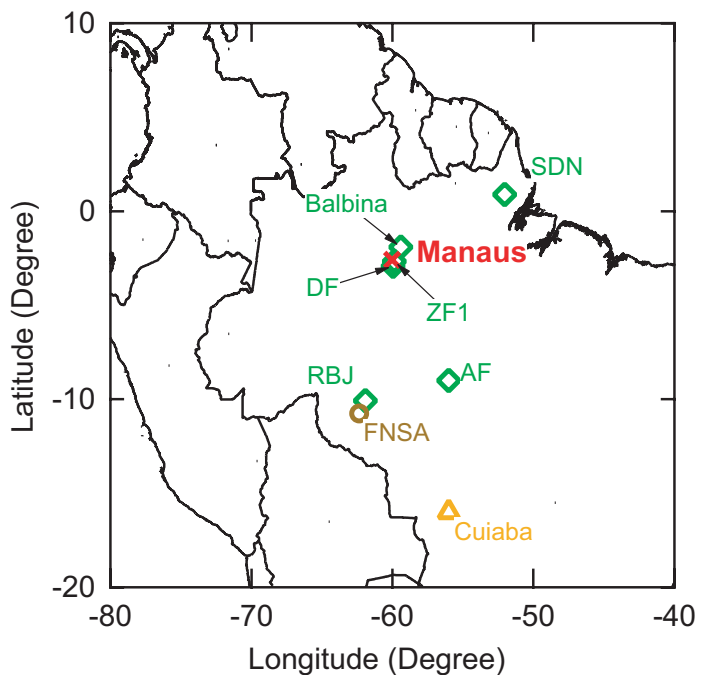

Fig. 1. EUCAARI sampling location Manaus (red cross) together with sampling sites cited in the paper and corresponding to literature studies: Balbina, AF (Alta Floresta), Cuiaba, FNSA (Fazenda Nossa Senhora Aparecida), DF (Ducke Forest), RBJ (Reserva Biologica Jarú), SDN (Serra do Navio), and ZF1 (Ducke Forest remote site); sites are color coded as forest (green), pasture area (brown), and Savanna (yellow).

while the second part (August-September) fell during the Amazonian dry season. Figure 2 shows the back-trajectories of air masses sampled during the different months; during the wet period air masses came mainly from the northeast, while the dry period was characterized by a larger variability, and the direction of back-trajectories varied from the northwest to the north to the southeast. Meteorological parameters averaged during the filter sampling periods are shown in Fig. 3a. Temperature did not differ significantly during the two seasons: the average value was $26^{\circ} \mathrm{C}$. The average relative humidity clearly decreased from $85 \%$ during the wet season to $75 \%$ during the dry season, and the average precipitation dropped from $11 \mathrm{~mm}$ to $5 \mathrm{~mm}$ per day. Rain events were observed almost every day, both during wet and dry season.

Aerosol particles were collected on $47 \mathrm{~mm}$ quartz filters at a flow rate of $16.7 \mathrm{~L} \mathrm{~min}^{-1}$; sampling period was $72 \mathrm{~h}$ due to low aerosol loading. Fine particles (aerodynamic diameter below $2.5 \mu \mathrm{m}$ ) and coarse particles (aerodynamic diameter between 2.5 and $10 \mu \mathrm{m}$ ) were collected simultaneously using a Dichotomous Partisol sampler (Rupprecht \& Patashnick Co., Inc). Quartz filters were not baked prior to collection.

Aerosol collection on quartz filters might lead to negative artifacts due to volatilization of ammonium nitrate and organic species, and to positive artifacts due to absorption of semi-volatile species, i.e. low molecular weight organics (Putaud et al. 2004 and reference therein). To avoid negative sampling artifacts, one Whatman 41 paper filter was sampled simultaneously on the back of each quartz filter used

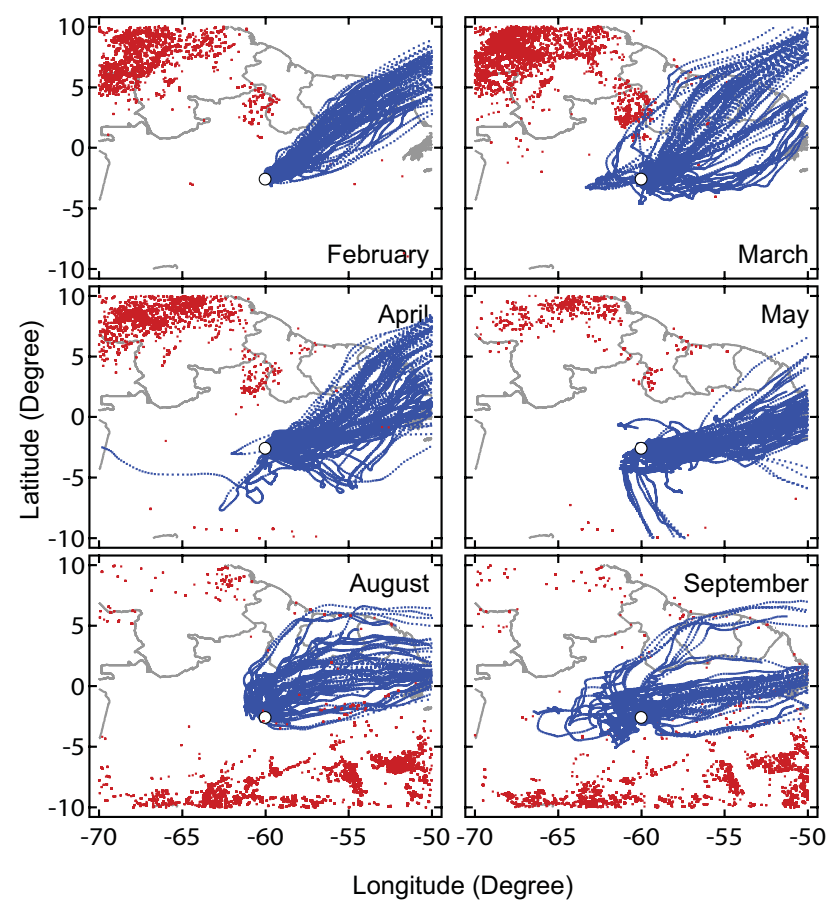

Fig. 2. Maps indicating 7-day back-trajectories (blue points) corresponding to the sampling intervals during each month of the collection campaign; sampling site is indicated by a white circle; red points indicate fire locations observed by MODIS.

to collect the fine aerosol fraction; in fact, paper collection substrate is less sensitive to volatilization losses of ammonium nitrate (Putaud et al., 2002). The concentration of ammonium and nitrate in the aerosol phase was then calculated as the sum of quartz and paper filter concentrations and the reconstructed chemical mass of fine particles included ammonium and nitrate from the two substrates. Denuder units were employed to avoid positive sampling artifacts: volatile organic carbon was removed from the sampled air upstream the filter with activated carbon honeycomb denuders, while gaseous nitric acid and ammonia were removed with two glass denuders coated with sodium chloride and citric acid, respectively.

\subsection{Aerosol chemical and gravimetrical analysis}

Fine and coarse mode aerosol masses were determined gravimetrically. Filters were weighted before and after sampling, after conditioning for $24 \mathrm{~h}$ at controlled temperature and relative humidity $\left(21 \pm 2{ }^{\circ} \mathrm{C}, 35 \pm 4 \%\right.$, on average). The mass detection limit, defined as the blank mass plus three times the blank standard deviation, was $1.1 \mu \mathrm{g} \mathrm{m}^{-3}$. The high detection limit is due to the variability of quartz blank filter weight; precision was about $15 \%$. Coarse aerosol mass concentration was above detection limit during the entire campaign, while the fraction of fine samples with detectable mass 


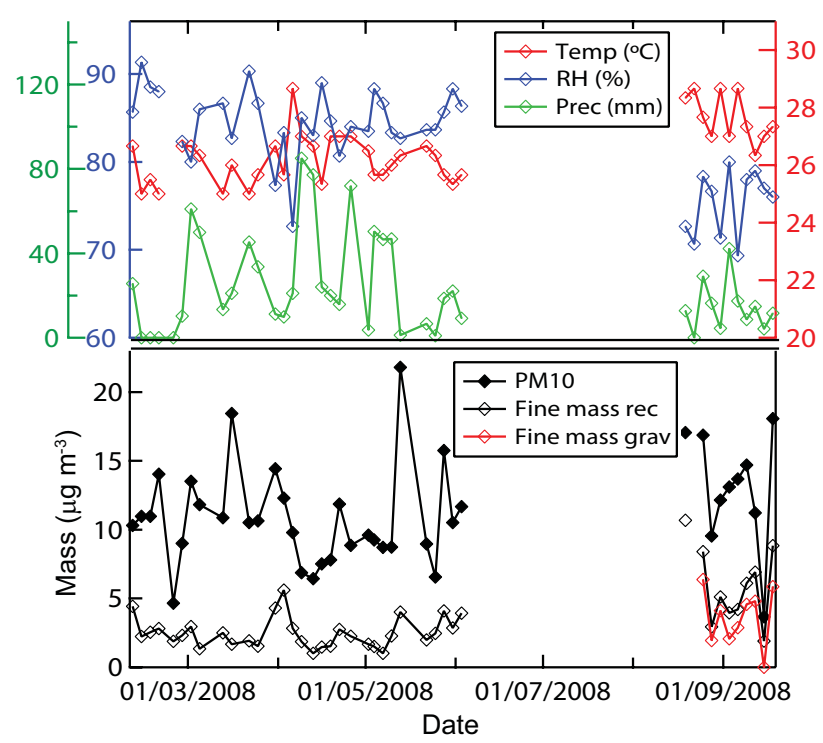

Fig. 3. Temporal trend of relative humidity, temperature, and precipitation during the EUCAARI campaign (a), together with the time series of fine mass (gravimetric mass in red and chemically reconstructed mass in black) and $\mathrm{PM}_{10}$ (b).

concentration was about $30 \%$ during the wet season and $90 \%$ during the dry season.

EC and OC concentrations were measured by thermaloptical analysis with a Sunset Laboratory Dual-Optical Carbonaceous analyzer. A modified version of protocol EUSAAR_2 (Cavalli et al., 2010) was employed; the protocol was modified with longer heating steps in order to assure the complete evolution of the carbon fractions. The uncertainties of OC and EC measurements averaged $25 \%$ and $50 \%$, respectively. The errors were determined based on the method reproducibility and the instrumental blanks (Birch and Cary, 1996).

Equivalent black carbon (EBC) was measured on the quartz filters with a light reflectance technique (smoke stain reflectometer model 43) that quantifies the light absorbing carbon deposited on each quartz filter from the reflectance of broadband visible light (Andreae, 1983; Andreae et al., 1984; Reid et al., 1998). This measurement technique, usually applied to polycarbonate filters, was here used on quartz filters (Graham et al., 2003; Guyon et al., 2003).

Punches of quartz and paper filters $(1.5 \mathrm{~cm}$ diameter $)$ were extracted with ultrapure water $(18.2 \mathrm{M} \Omega \mathrm{cm})$ and analyzed by ion chromatography to determine major water soluble inorganic ion concentrations (chloride, nitrate, phosphate, sulfate, sodium, ammonium, potassium, magnesium, and calcium). Assuming that the ion balance of water extracts was neutral, carbonate concentration was calculated from the difference between the number of cation and anion equivalents. Such a difference was close to zero for fine aerosol samples and larger than zero for coarse particles, where carbonate was expected to be associated to soil dust. Still the amount of carbonate (less than $2 \%$ of coarse mass) was negligible compared to OM (on average $83 \%$ of coarse mass) to interfere with carbonaceous aerosol thermal-optical analysis.

As part of the quality control procedure, an aliquot of standard reference material SRM 2694 (simulated rainwater) was analyzed simultaneously to each sample batch and the agreement between certified values and measured concentrations was verified. The ion concentration uncertainty was calculated with the propagation error formula and taking into account the integration, calibration, dilution errors, and the blank variability. Chloride, nitrate, sodium, and magnesium showed the highest uncertainties $(30 \%-40 \%)$; for ammonium, calcium, and carbonate the average uncertainty ranged between $20 \%$ and $30 \%$, while for potassium and sulfate the uncertainty was smaller than $15 \%$. For all the species the propagated error values was dominated by blank variability.

\subsection{PMF analysis of thermograms}

Several authors investigated Amazon aerosol sources. Some of them used tracer analysis (Claeys et al., 2010), that leads to a detailed identification of a certain fraction of aerosol sources, other authors (Artaxo et al., 1990; Echalar et al., 1998; Guyon et al., 2004) used Principal Component Analysis (PCA) and Absolute Principal Component Analysis (APCA), which apportion the entire mass even if with less details. Compared to PCA, Positive Matrix Factorization (PMF) is a more recent advance in source apportionment and has several advantages. PMF scales each data point individually on the basis of its uncertainty and this is important for remote sites where concentrations are often close to the detection limits. In addition, PMF constrains solutions to be positive. As PCA, PMF does not require to know the source profiles to apportion the different aerosol sources. PMF analysis of infrared spectra (Liu et al., 2009; Russell et al., 2009) and mass spectra (Zhang et al., 2007) was successfully used to identify carbonaceous aerosol sources in urban, rural and remote locations.

The innovative idea presented in this paper is the use of PMF applied to thermograms obtained from thermal-optical analysis of the carbonaceous fraction of fine and coarse aerosols. The information that can be obtained by thermaloptical analysis is often summarized by volatility classes, i.e. the amount of carbon that evolves during each heating step. The PMF analysis of thermograms allowed us to use the information about the thermal evolution curve at each heating step to obtain further insights about the properties and composition of each class. In fact, the way each class thermally evolves depends on the thermal properties of the species that compose each class (Grosjean et al., 1994; Peralta et al., 2007).

Carbonaceous aerosol sources were identified with Positive Matrix Factorization (PMF) analysis of sample thermograms using EPA PMF 3.0 software (Norris et al., 2008). 
The term thermogram indicates the flame ionization detector (FID) response recorded versus time during the thermaloptical ECOC analysis. To reduce the noise level, thermograms were smoothed with a simple running average, reducing to $10 \%$ the original number of points. The initial $20 \mathrm{~s}$ and the last $120 \mathrm{~s}$ of each thermogram were discarded to eliminate noise associated to the initial fluctuation of temperature and to remove the calibration signal at the end of the thermogram.

In PMF each sample is weighted according to its overall uncertainty, which can be estimated using the analytical uncertainty plus the method detection limit (Polissar et al., 1998). Since each analysis could not be replicated more than once, it was not possible to quantify the analytical error and apply the formula suggested by Polissar et al. (1998). Instead, we estimated the overall uncertainty using the repeatability uncertainty and the minimum detection limit. The error matrix was here defined as three times the standard deviation of the FID signal recorded during the blank analysis. Variables with a probability larger than $10 \%$ to have scaled residuals larger than 5 were used as weak variables. This criterion identified as weak variables those describing the volatility behavior below $200^{\circ} \mathrm{C}$, thus corresponding to the most volatile fraction of organic carbon. This result is consistent with a larger uncertainty associated to those species that more easily partition between the gas and the aerosol phase.

To define the number of factors we took into account previous source apportionment studies in the Amazon area. Artaxo et al. (1990) described fine and coarse aerosol mass using two components with APCA. Guyon et al. (2004) reconstructed aerosol mass in a forest site using 4 components: one was assigned to biomass burning, two components associated to biogenic aerosol, and the fourth component remained unassigned. Based on these literature studies we considered unlikely the presence of more than 4 sources, and thus the need of more than 4 profiles. Then, we investigated how the number of factors affected the quality of fit through the $Q$ parameter, and the dependency of different factors. Three factors were used to explain both fine and coarse carbonaceous aerosol mass, since they minimized the $Q_{\text {robust }}$ to $Q_{\text {theoretical }}$ ratio. The $Q$ parameters corresponding to the fine aerosol analysis were $Q_{\text {theoretical }}=5931, Q_{\text {robust }}=4244$, and $Q_{\text {true }}$ $=4735$, while the coarse aerosol analysis led to $Q_{\text {theoretical }}$ $=5931, Q_{\text {robust }}=4243$, and $Q_{\text {true }}=4314$. The three factors were independent both for fine and coarse dataset.

In order to optimize the results of PMF analysis, the rotational freedom of the PMF solutions was investigated through the tuning of $F_{\text {peak }}$ values between -2 and +2 (Paatero et al., 2000). $\quad F_{\text {peak }}$ equal to zero was chosen as the best solution, since no significant improvement was observed in the correlation between source profiles and ambient aerosol profiles by setting $F_{\text {peak }}$ different from zero.

\subsection{Modeling of aerosol chemical composition}

The global chemistry transport model TM5 was applied to simulate the aerosol concentrations of organic and inorganic species. TM5 is an off-line global model (Krol et al., 2005) that uses as input the meteorological data of the ECMWF model and provides aerosol species and trace gas distribution based on global emissions. It has a spatial resolution of $6^{\circ} \times 4^{\circ}$; a two-way zooming algorithm was applied over South-America to obtain a resolution of $1^{\circ} \times 1^{\circ}$. The vertical structure is composed by 25 layers up to $100 \mathrm{mbar}$ with a higher resolution in the boundary layer and around the tropopause. The height of the first layer is approximately $50 \mathrm{~m}$.

Surface processes are globally treated on a resolution of $1^{\circ} \times 1^{\circ}$. Photochemistry and aerosols are coupled in this version of the model. Particles, which are internally mixed and can contain sulfate, ammonium, and nitrate are described using a bulk approach, even though for the calculations of the scavenging processes they are implicitly assumed to be in the accumulation mode. The model treats $\mathrm{BC}$ and $\mathrm{OC}$ as primary aerosols and does not calculate the SOA; however, following the suggestions from the AEROCOM exercise (Dentener et al., 2006) SOA are treated as primary and emitted in the model atmosphere.

Gas phase chemistry is calculated using the CBM-IV chemical mechanism (Gery et al., 1989a,b) modified by Houweling et al. (1998), solved using the EBI method (Hertel et al., 1993). The equilibrium model EQSAM (Metzger et al., 2002b,a) is used to calculate the partitioning between the aerosol and gas phases of ammonia, nitric acid, ammonium and nitrate and the water attached to the particle in equilibrium with the water vapor. Sulfate is assumed present only in the aerosol phase. It is formed by the oxidation of $\mathrm{SO}_{2}$ (and DMS) in the gas phase by $\mathrm{OH}$ and in the aqueous phase by $\mathrm{H}_{2} \mathrm{O}_{2}$ and ozone.

Dry deposition is calculated using the ECMWF surface characteristics and the resistance method (Ganzeveld and Lelieveld, 1995).

Wet deposition is the dominant removal process for most aerosols. Removal occurs in convective systems (convective precipitation) and in large-scale stratiform systems that are associated with weather fronts. The in-cloud removal rates, which depend on the precipitation rate, are differentiated for convective and stratiform precipitation and are calculated following Guelle et al. (1998) and Jeuken et al. (2001). Aerosol below-cloud scavenging is parameterized according to Dana and Hales (1976).

The emission inventories are from the Hemispheric Transport of Air Pollution exercise (TF HTAP, 2007). Although defined as $\mathrm{BC}$ emission inventories the inventories used in this work were constructed using emission factors predominantly based on thermal-optical measurements and therefore they represent a more elemental carbon-like carbonaceous compound rather than BC (Vignati et al., 2010). Thus it is 
more appropriate to compare the modeled values with $\mathrm{EC}$ measurements.

The model has been evaluated in model intercomparison exercises (Textor et al., 2006), using in-situ, satellite and sunphotometer measurements (de Meij et al., 2006; Vignati et al., 2010), and applied for the year 2001. Outputs of monthly averaged surface fields are used for the analysis.

\section{Results}

\subsection{Fine and coarse mass}

Table 1 shows the average concentrations of gravimetric aerosol mass, reconstructed chemical mass, and carbonaceous species, together with the concentration of noncarbonaceous species as reference; the averages were calculated only including values above detection limit. The reconstructed chemical mass was calculated using the organic mass $(\mathrm{OM})$ to $\mathrm{OC}$ ratio of 1.7 for fine aerosol mode and 1.4 for coarse aerosol particles. The OM to OC ratio is expected to range between 1.4 for less oxidized/fresh aerosol and 2.2 for more oxidized/aged aerosol (Gilardoni et al., 2009; Russell, 2003). The fine aerosol mode ratio of 1.7 was chosen accordingly to the value determined for submicron particles by AMS measurements (Chen et al., 2009), while the ratio 1.4 was used for coarse particles because coarse OC is expected to be mainly primary biogenic. To the best of our knowledge no direct measurements of the OM/OC is available for PBAP. The authors assumed that PBAP was dominated by aliphatic functional groups and consequently used the lower bound of the OM/OC ratio reported by Russell (2003).

Fine aerosol mass during the wet season was most of the time close or below detection limit $\left(1.1 \mu \mathrm{g} \mathrm{m}^{-3}\right)$ and the reconstructed chemical mass was $2.4 \mu \mathrm{g} \mathrm{m}^{-3}$. During the dry season fine mass concentration almost doubled, averaging $4.2 \mu \mathrm{g} \mathrm{m}^{-3}$; including the sum of ammonium and nitrate concentration from quartz and paper filters, the corresponding reconstructed mass $\left(5.5 \mu \mathrm{g} \mathrm{m}^{-3}\right)$ was larger than the gravimetric average. The mass of coarse aerosol mode averaged 7.9 and $7.6 \mu \mathrm{g} \mathrm{m}^{-3}$ during wet and dry season, respectively, with the chemical reconstructed masses explaining 90 and $92 \%$ of the gravimetric masses. Mass concentrations reported in this study agreed within experimental error with the concentrations measured with stacked filter unit (SFU) system deployed at the same site (see Table 1 for comparison).

Figure $3 \mathrm{~b}$ shows the time series of fine aerosol mass together with $\mathrm{PM}_{10}$ mass, where $\mathrm{PM}_{10}$ was calculated as the sum of fine and coarse mass. Fine mass clearly increased passing from the wet to the dry period, while $\mathrm{PM}_{10}$ was quite variable during the entire campaign, and it did not show any seasonality. $\mathrm{PM}_{10}$ concentration averaged $10.3 \mu \mathrm{g} \mathrm{m}^{-3}$ during the wet season and $11.4 \mathrm{\mu g} \mathrm{m}^{-3}$ during the dry season. The contribution of fine particles to aerosol loading during the dry season was 2 times larger compared to the wet season: on average fine particle mass represented $21 \%$ of $\mathrm{PM}_{10}$ (10 to $40 \%$ ) during the wet months, and $39 \%$ (25 to 60\%) during the dry ones; yet, the seasonal difference was not as marked as in forest areas strongly affected by biomass burning, where the average contribution of fine particles to $\mathrm{PM}_{10}$ was $60 \%$ (Alta Floresta) (Echalar et al., 1998) and 80\% (Rondônia) (Artaxo et al., 2002) during the dry season.

Concentrations of fine aerosol larger than $4 \mu \mathrm{g} \mathrm{m}^{-3}$ were associated with lower precipitation rate (below $10 \mathrm{~mm} \mathrm{day}^{-1}$ ), suggesting that sources and removal mechanisms of fine particles were affected by weather conditions: dry weather promoted biomass burning and increased fine particle concentration, while rain scavenged fine particles and reduced fine mass concentration. Conversely, coarse aerosol concentration was not affected by rain events. This is consistent with the large contribution of primary biological aerosol particles to the coarse mass and the fact that wet weather conditions have opposite effects on PBAP concentration: rain removes this kind of particles and water vapor promotes their release (Graham et al., 2003).

\subsection{Carbonaceous aerosol}

The percentage contributions of OM, EC and inorganic ions to fine and coarse mass are displayed in Table 1. Although the absolute species concentration varied passing from the wet to the dry season, no relevant differences were noted in the mass percentage composition. The most abundant component of fine and coarse aerosol mass was OC. In the fine aerosol mode the OC to mass ratio was 0.4 , while in the coarse mode the ratio was equal to 0.6. On average OM concentration represented $72 \%$ of fine mass and $85 \%$ of coarse mass. During the wet season the OM concentration of fine aerosol mode average $1.7 \mu \mathrm{g} \mathrm{m}^{-3}$, slightly larger than the concentrations measured with AMS in submicron particles $\left(0.6-0.9 \mu \mathrm{g} \mathrm{m}^{-3}\right)$ (Chen et al., 2009); the comparison indicates that the submicron OM represented $40 \%-60 \%$ of fine mode OM.

OC fine concentration increased during the dry season, while OC coarse was similar during the two periods. The different seasonal variability is due to different sources of OC fine and coarse. OC fine during the dry months received a large contribution from forest and savanna burning emissions, not as important during the wet months. On the other side, OC coarse is associated mainly to PBAP (Pöschl et al., 2010), whose release seemed not be affected by seasonality (Echalar et al., 1998).

The seasonality of soot concentration, determined from $\mathrm{EC}$ and $\mathrm{EBC}$ measurements, was similar to that of fine OC. Higher values were measured during the dry season, when a larger number of fires was intercepted by the backtrajectories reaching the site, as shown in Fig. 2. EC and EBC were present mainly in fine aerosol particles, while their concentration in coarse particle was often below detection limit, 
Table 1. Time weighted average concentrations and mass percentage contribution of aerosol species. Concentrations are in $\mathrm{ng}^{-3}, \mathrm{SD}^{-}$is the standard deviation, and $n$ is the number of samples in which the concentration was above detection limit.

\begin{tabular}{|c|c|c|c|c|c|c|c|c|c|c|c|c|c|c|c|c|c|c|}
\hline \multirow[t]{3}{*}{ Species } & \multicolumn{9}{|c|}{ Fine } & \multicolumn{9}{|c|}{ Coarse } \\
\hline & \multicolumn{3}{|c|}{ All } & \multicolumn{3}{|c|}{ Wet } & \multicolumn{3}{|c|}{ Dry } & \multicolumn{3}{|c|}{ All } & \multicolumn{3}{|c|}{ Wet } & \multicolumn{3}{|c|}{ Dry } \\
\hline & Mean & SD & $n$ & Mean & $\mathrm{SD}$ & $n$ & Mean & SD & $n$ & Mean & SD & $n$ & Mean & SD & $n$ & Mean & SD & $n$ \\
\hline Mass $^{\mathrm{a}}$ & - & - & - & - & - & - & 4.2 & 1.5 & 9 & 7.8 & 2.4 & 34 & 7.9 & 2.9 & 24 & 7.6 & 2.7 & 10 \\
\hline Rec Mass ${ }^{a}$ & 3.0 & 2.1 & 42 & 2.4 & 1.4 & 30 & 5.5 & 3.0 & 12 & 7.3 & 3.0 & 42 & 7.4 & 3.0 & 30 & 6.9 & 2.4 & 12 \\
\hline SFU Mass & 2.5 & 2.3 & 31 & 1.6 & 0.9 & 24 & 4.7 & 2.0 & 7 & 6.4 & 2.4 & 31 & 6.0 & 2.6 & 24 & 7.4 & 3.2 & 7 \\
\hline $\mathrm{OC}^{\mathrm{a}}$ & 1.4 & 0.9 & 42 & 1 & 1.4 & 30 & 2.3 & 2 & 12 & 4.7 & 2.5 & 42 & 4.7 & 2.6 & 30 & 4.5 & 2.4 & 12 \\
\hline $\mathrm{EC}$ & 150 & 120 & 41 & 110 & 80 & 30 & 240 & 160 & 11 & 50 & 40 & 25 & 50 & 40 & 22 & 20 & 10 & 3 \\
\hline EBC & 256 & 260 & 40 & 130 & 100 & 30 & 520 & 330 & 10 & 50 & 20 & 36 & 60 & 20 & 29 & 20 & 10 & 7 \\
\hline $\mathrm{SO}_{4}^{2-}$ & 470 & 380 & 40 & 310 & 220 & 30 & 880 & 420 & 10 & 70 & 60 & 36 & 80 & 140 & 25 & 60 & 30 & 11 \\
\hline $\mathrm{CO}_{3}^{2-}-$ & - & & & - & & & - & & & 130 & 70 & 42 & 130 & 70 & 30 & 130 & 70 & 12 \\
\hline $\mathrm{NO}_{3}^{-}$ & 90 & 60 & 39 & 90 & 60 & 27 & 80 & 40 & 12 & 90 & 40 & 15 & - & & & 110 & 50 & 7 \\
\hline $\mathrm{Cl}^{-}{ }^{3}$ & - & & & - & & & - & & & 110 & 80 & 5 & 120 & 60 & 5 & - & & \\
\hline $\mathrm{NH}_{4}^{+}$ & 180 & 150 & 38 & 110 & 80 & 27 & 350 & 160 & 11 & - & & & - & & & - & & \\
\hline $\mathrm{K}^{+}$ & 60 & 70 & 32 & 30 & 20 & 22 & 130 & 80 & 10 & 60 & 40 & 39 & 70 & 30 & 29 & 60 & 20 & 10 \\
\hline $\mathrm{Na}^{+}$ & 80 & 70 & 16 & 50 & 30 & 10 & 120 & 80 & 6 & 80 & 50 & 21 & 80 & 50 & 12 & 70 & 50 & 9 \\
\hline $\mathrm{Ca}^{2+}$ & 40 & 20 & 31 & 40 & 20 & 23 & 40 & 20 & 8 & 40 & 40 & 42 & 50 & 50 & 30 & 40 & 20 & 12 \\
\hline $\mathrm{Mg}^{2+}$ & - & & & - & & & - & & & 20 & 10 & 36 & 20 & 10 & 26 & 30 & 10 & 10 \\
\hline $\mathrm{OM}^{\mathrm{b}}$ & $72 \%$ & & & $72 \%$ & & & $71 \%$ & & & $85 \%$ & & & $85 \%$ & & & $83 \%$ & & \\
\hline $\mathrm{EC}$ & $4 \%$ & & & $4 \%$ & & & $4 \%$ & & & $<1 \%$ & & & $<1 \%$ & & & - & & \\
\hline $\mathrm{SO}_{4}^{2-}$ & $13 \%$ & & & $12 \%$ & & & $15 \%$ & & & $<1 \%$ & & & $<1 \%$ & & & $<1 \%$ & & \\
\hline $\mathrm{CO}_{3}^{2-}$ & - & & & - & & & - & & & $1 \%$ & & & $1 \%$ & & & $2 \%$ & & \\
\hline $\mathrm{NO}_{3}^{-}$ & $3 \%$ & & & $4 \%$ & & & $1 \%$ & & & $1 \%$ & & & $<1 \%$ & & & $1 \%$ & & \\
\hline $\mathrm{NH}_{4}^{+}$ & $5 \%$ & & & $4 \%$ & & & $6 \%$ & & & $<1 \%$ & & & $<1 \%$ & & & - & & \\
\hline
\end{tabular}

a Mass and $\mathrm{OC}$ concentrations are in $\mu \mathrm{g} \mathrm{m}-3$.

b $\mathrm{OM}$ is calculated using $\mathrm{OM} / \mathrm{OC}$ equal to 1.7 for fine mode and 1.4 for coarse mode particles..

and for this reason coarse EBC will not be discussed in this paper.

During the wet season fine particle EC and EBC concentration agreed within the experimental error and their averages were 110 and $130 \mathrm{ng} \mathrm{m}^{-3}$, respectively. The EBC to fine mass ratio was about 0.06 in agreement with the values reported for Balbina, a forest site near Manaus in 1998 and 2001(Pauliquevis et al., 2007). The presence of a nonnegligible amount of soot during the wet season might be related both to the use of biomass burning for home cooking throughout the year, to the influence of South-American Northern Hemisphere fires, and to the long range transport of combustion aerosol from Africa, as occasionally observed (see Sect. 3.3).

Aerosol light absorption coefficient (Babs) was measured in parallel with a Multi Angle Absorption Photometer (MAAP) from February 2008 till July 2009. Due to instrumental failures, measurements were interrupted during August and September 2008, limiting the comparison with chemical composition data to the wet season. Figure 4 shows the correlation of Babs at $637 \mathrm{~nm}$ and elemental carbon concentration in $\mathrm{PM}_{10}$ aerosol mode $\left(r^{2}=0.83\right)$; Babs were calculated as the average of $60 \mathrm{~min}$ resolution data integrated over the filter collection periods. The error bars displayed in the graph correspond to uncertainty of EC measurements (on the $\mathrm{x}$-axis) and variability of aerosol absorption coefficient over the integrating period (on the y-axis). The mass absorption cross section (MAC), corresponding to the slope of the orthogonal linear fit, was $4.7 \mathrm{~m}^{2} \mathrm{~g}^{-1}$. At our best knowledge this is the first measurement of MAC in a regional background site in Amazonia. Although the large error bars, the data points are clearly located below the 6.6 slope line corresponding to the MAC suggested by the instrument manufacturer at the same wavelength. Moreover, the MAC observed in urban sites and adjusted to $637 \mathrm{~nm}$ are usually higher than one we observed; for example, the values measured by Petzold and Schönlinner (2004) ranged between 7.8 and $9.2 \mathrm{~m}^{2} \mathrm{~g}^{-1}$, while Bond and Bergstrom (2006) suggested to use a value of $6.4 \mathrm{~m}^{2} \mathrm{~g}^{-1}$. The smaller MAC in Manaus compared to that of more polluted sites is likely due to a smaller soot particle coating and consequently smaller coating lens effect, in agreement with the trend observed by Liousse et al. (1993) during the comparison of urban and remote sites. 


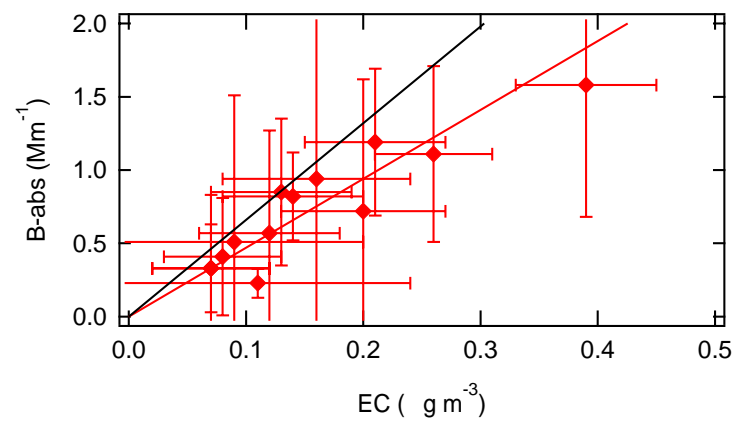

Fig. 4. Orthogonal linear fit of MAAP light absorption coefficient (Babs) and thermal-optical EC concentration (red); the black line corresponds to the absorption cross section of 6.6 suggested by the instrument manufacturer to convert Babs into EBC.

During the dry season fine particle EC and EBC concentrations averaged 240 and $530 \mathrm{ng} \mathrm{m}^{-3}$, respectively. Figure 5a shows that the dry season EBC was generally two times larger than the corresponding EC.

Previous studies showed that the fine EBC concentrations measured in Balbina at the end of the wet period (Graham et al., 2003) was about 6 times larger than EC values; similarly, Guyon et al. (2003) reported that EBC above the canopy level in Rondônia was about 3 times larger than EC. The difference between EC and EBC was attributed to PBAP in fine aerosol, able to absorb visible light, and thus leading to overestimation of EBC. This conclusion does not apply to the analysis performed in this study, since the discrepancy was observed only during the dry period and the concentration of PBAP in fine particles was negligible.

The discrepancy between EC and EBC measurements observed in this study could be justified by the underestimation of EC or overestimation of EBC.

Underestimation of EC occurs when some fractions of EC evolved during the first stage of the thermal-optical analysis, in He-mode, together with the $\mathrm{OC}$ fraction. To avoid this source of uncertainty the maximum temperature reached in $\mathrm{He}$ atmosphere was set equal to $650^{\circ} \mathrm{C}$ (Cavalli et al., 2010). The premature evolution of EC was ruled out by the analysis of laser transmittance acquired during the EC/OC analysis. In fact, EC is able to absorb laser light (wavelength $678 \mathrm{~nm}$ ), and when it evolves, laser transmittance through the filter increases. During the analysis of samples in this study the laser signal reached its minimum at $650^{\circ}$ and did not increase until the $\mathrm{He} / \mathrm{O}_{2}$ mode, indicating no loss of $\mathrm{EC}$ during the $\mathrm{He}$ mode.

The presence of light absorbing species, different than carbon, might lead to an overestimation of EBC, especially when broadband visible light is employed; for example, dust might interferes with EBC measurements because some mineral components, like hematite, are able to absorb the short wavelengths. To exclude overestimation of EBC due to dust transport not related to fire events, Fig. $5 \mathrm{~b}$ shows the compar-
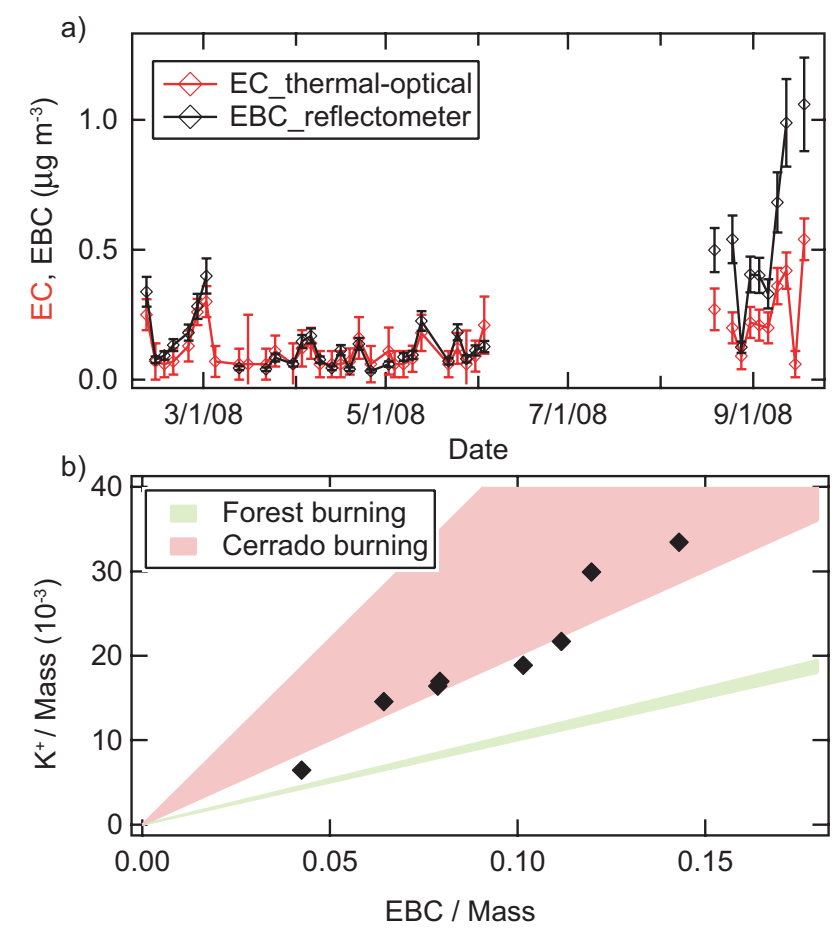

Fig. 5. Time series of elemental carbon (red) and equivalent black carbon (black) concentration in fine aerosol (a). Comparison of potassium and equivalent black carbon concentration during the dry season (August and September) normalized to fine aerosol mass (b); shadowed areas correspond to $\mathrm{K}^{+}$to $\mathrm{EBC}$ ratio expected from cerrado (red) and forest (green) burning (Yamasoe et al., 2000).

ison of soluble potassium and EBC concentration normalized to fine mass. EBC is emitted by combustion processes, and soluble potassium is a tracer for biomass burning, as well as dust. The scatter plot indicates that $\mathrm{EBC}$ and $\mathrm{K}^{+}$correlated during the dry period $\left(r^{2}=0.93\right)$, with slope equal to 0.22 . The $\mathrm{K}^{+}$to EBC ratios lied between the ratios expected for vegetation flaming and smoldering (0.10-0.24), confirming that vegetation fires were the main sources of both $\mathrm{K}^{+}$and EBC during the dry season.

In addition to dust, organic species released during fires can contribute to the overestimation of EC and to a larger extent to that of EBC. Reid et al. (1998) already observed a discrepancy larger than $40 \%$ between EBC and EC during the analysis of smoke plume in the framework of the SCAR-B experiment in Brazil. It is known that vegetation combustion produces a class of organic species, defined as brown carbon, able to absorb visible light as a consequence of aromatic and unsaturated hydrocarbon molecular structure (Alexander et al., 2008; Andreae and Gelencser, 2006). Brown carbon is part of OC fraction, but since it absorbs radiation with wavelengths smaller than $650 \mathrm{~nm}$ (Kirchstetter et al., 2004), it is accounted as EBC by optical techniques that use visible broadband light (390-750 nm). This would lead to a larger EBC concentration compared to EC. 
Based on the set of data available during the dry season, we are not able to discriminate between fire resuspended dust and brown carbon as source of interference during EBC measurements.

\subsection{Pyrogenic aerosol events during the wet season}

EC concentrations from 10 to 13 February and from 23 February to 3 March were two to three times larger than the average observed during the wet months and similar to the concentrations of the dry period, indicating the likely influence of combustion emissions. During the wet season fires in South America were located to the northwest of the sampling site while the back-trajectories were from the northeast excluding the influence of South America open burning emissions.

During the same periods the concentration of nitrate and sulfate went up to $630 \mathrm{ng} \mathrm{m}^{-3}$ and $250 \mathrm{ng} \mathrm{m}^{-3}$, respectively, largely higher than the seasonal averages (Table 1). Aerosol sulfate and nitrate are produced by the oxidation of sulfur and nitrogen oxides to form nitric and sulfuric acids; these acids are then neutralized by ammonia in the aerosol phase. During most of the sampling campaign the equivalent concentration of sulfate and nitrate correlated very well with ammonium with a slope close to one $\left(1.01 \pm 0.04, r^{2}=0.86\right)$, indicating that ammonium fully neutralized the acids as $\mathrm{NH}_{4} \mathrm{NO}_{3}$ and $\left(\mathrm{NH}_{4}\right)_{2} \mathrm{SO}_{4}$. During the pyrogenic aerosol events of 10-13 February and 23 February-3 March the equivalent ratio of $\mathrm{SO}_{4}^{2-}$ and $\mathrm{NO}_{3}^{-}$relative to $\mathrm{NH}_{4}^{+}$was larger than two.

Elemental analysis of aerosol samples collected in parallel showed that during the pyrogenic events, dust concentration was significantly higher than the background (Prenni et al., 2009). The heterogeneous reaction of dust with acidic species (Usher et al., 2003; Feng and Penner, 2007; Hwang and Ro, 2006) justifies the enhanced concentration of nitrate and sulfate relative to ammonium. Moreover, global chemistry transport model and Raman LIDAR measurements indicated that dust aerosol observed in February in Manaus was transported from the Sahara region (Ansmann et al., 2009; Prenni et al., 2009).

The concomitant peaks of African dust and biomass burning tracers in February suggests that the pyrogenic aerosol events observed in Manaus during the wet season were due to African biomass burning emissions. This is consistent with African seasonality of biomass burning, that goes from October to March and occurs mainly in the Sahel, south of the Sahara area (Roberts et al., 2009). These observations indicate that out-of-continent biomass burning can contribute significantly to the loading and optical properties of fine aerosol during the wet season.

\section{Discussion}

\subsection{Comparison with previous studies}

For comparison the average fine and coarse mass concentration in South-America regional background sites during the last $20 \mathrm{yr}$ are presented in Table 2. Data reported refer to measurement periods longer than 30 days, to guarantee the representativeness of the mean values; for OC shorter period measurements are included due to the lack of data. The sites (Fig. 1) are classified as forest, pasture, and savanna areas. The forest type indicates sampling locations surrounded by pristine rain forest; among the forest group, Alta Floresta is the only site characterized by nearby land clearing and anthropogenic activities (i.e. strong land use change and gold mining) (Echalar et al., 1998). Pasture sites are strongly affected by biomass burning due to agricultural or land clearing activities, especially during the dry months. Similarly, savanna sites are heavily affected by regional wildfire burning emissions.

Fine mass during the dry season averaged 64,37 , and $30 \mu \mathrm{g} \mathrm{m}^{-3}$ in the pasture, forest, and savanna areas, respectively. The average dry fine mass in the forest sites was about ten times higher compared to the concentration measured during the present study, and it was even higher than the savanna mean value. The forest fine mass concentration showed a large variability from site to site, and the high average is due to the higher concentrations observed at the two sites in Rondônia (Alta Floresta and Reserva Biologica Jarú). The concentrations measured in this study were of the same order of magnitude of those measured at Balbina, a forest site located $100 \mathrm{~km}$ to the northwest.

Coarse mass concentration did not differ significantly for the different site categories; the average values during wet and dry season were 12 and $32 \mu \mathrm{g} \mathrm{m}^{-3}$ in the savanna sites, 8 and $21 \mu \mathrm{g} \mathrm{m}^{-3}$ in the forest, and 6 and $17 \mu \mathrm{g} \mathrm{m}^{-3}$ in the pasture areas, respectively. Literature reports short episodes characterized by very high coarse mass concentration (higher than $50 \mu \mathrm{g} \mathrm{m}^{-3}$ ) that were related to long-range transport events of Saharan dust (Artaxo et al., 1994; Talbot, 1990). Excluding Alta Floresta among the forest sites, because of occasional anthropogenic influence, the forest average coarse mode mass concentration would be 6 and $7 \mu \mathrm{g} \mathrm{m}^{-3}$ during the wet and dry season, respectively. Those values are very similar to the concentrations observed in this study.

Equivalent black carbon (EBC) in the South America regional background sites is a tracer of biomass burning emissions as well as other absorbing aerosols, such as biogenic and long range transport of industrial emissions; the comparison of EBC concentration among different sites helps us to understand the seasonality and the time variability of these sources. Unfortunately EBC is strongly dependent on the analytical technique employed for its measurements, so the comparison between values measured by different techniques and during different campaigns might be 
Table 2. Aerosol mass, equivalent black carbon, and organic carbon concentration in regional background sites in Brazil: Fazenda Nossa Senhora Aparecida (FNSA), Reserva Biologica Jarú (RBJ), Ducke Forest (DF), Ducke Forest meteorological station (DFM), Alta Floresta $(\mathrm{AF})$, and Serra do Navio (SDN); letter between brackets indicates site type: $\mathrm{P}=$ pasture, $\mathrm{S}=$ savanna, and $\mathrm{F}=$ forest.

\begin{tabular}{|c|c|c|c|c|c|c|}
\hline Site & Season & $\begin{array}{r}\text { Size range } \\
\mu \mathrm{m}\end{array}$ & $\begin{array}{r}\text { Mass } \\
\mu \mathrm{g} \mathrm{m}{ }^{-3}\end{array}$ & $\begin{array}{r}\mathrm{EBC} \\
\mu \mathrm{g} \mathrm{m}^{-3}\end{array}$ & $\begin{array}{r}\mathrm{OC} \\
\mu \mathrm{g} \mathrm{m}^{-3}\end{array}$ & Reference \\
\hline \multirow[t]{6}{*}{ FNSA (P) } & Dry & $0-2$ & 61.7 & & 26.9 & Falkovich et al. (2005) \\
\hline & Dry & $2-10$ & 16.5 & & & Decesari et al. (2006) \\
\hline & Trans & $0-2$ & & & 8.0 & \\
\hline & Trans & $2-10$ & & & & \\
\hline & Wet & $0-2$ & & & 1.4 & \\
\hline & Wet & $2-10$ & & & & \\
\hline FNSA $(\mathrm{P})$ & Dry & $0-2.5$ & & & 43.9 & Soto-Garcia et al., 2010 \\
\hline \multirow[t]{4}{*}{ FNSA (P) } & Dry & $0-2$ & 66.9 & 7.42 & & Artaxo et al. (2002) \\
\hline & Dry & $2-10$ & 17.8 & & & Guyon et al. (2003) \\
\hline & Wet & $0-2$ & 2.9 & 0.48 & & \\
\hline & Wet & $2-10$ & 5.7 & & & \\
\hline RBJ - & Dry & $0-2$ & 27.9 & 1.7 & & \\
\hline \multirow[t]{3}{*}{ in canopy $(\mathrm{F})$} & Dry & $2-10$ & 7.6 & & & \\
\hline & Wet & $0-2$ & 2.2 & 0.28 & & \\
\hline & Wet & $2-10$ & 6.6 & & & \\
\hline \multirow[t]{2}{*}{$\mathrm{DF}(\mathrm{F})$} & Wet & $0-2$ & 1.8 & & & Artaxo et al. (1990) \\
\hline & Wet & $2-15$ & 3.5 & & & \\
\hline \multirow[t]{2}{*}{ DFM (F) } & Wet & $0-2$ & 1.8 & & & \\
\hline & Wet & $2-15$ & 8 & & & \\
\hline \multirow{2}{*}{ ZF1 (F) } & Wet & $0-2$ & 1.7 & & & \\
\hline & Wet & $2-15$ & 6.5 & & & \\
\hline \multirow[t]{7}{*}{ Balbina $(F)$} & Dry & $0-2.5$ & 6.2 & 0.49 & & Pauliquevis et al. (2007) \\
\hline & Dry & $2.5-10$ & 7.2 & 0.05 & & \\
\hline & Wet & $0-2.5$ & 2.2 & 0.16 & & \\
\hline & Wet & $2.5-10$ & 6.6 & 0.05 & & \\
\hline & All & $0-10$ & 11 & & & \\
\hline & All & $0-2.5$ & & 0.17 & & \\
\hline & All & $2.5-10$ & & 0.05 & & \\
\hline \multirow[t]{2}{*}{ Balbina $(F)$} & Wet & $0-2$ & 2.6 & 0.29 & 1.1 & Graham et al. (2003) \\
\hline & Wet & $2-10$ & 3.9 & 0.07 & 2.3 & \\
\hline \multirow[t]{2}{*}{ Balbina $(F)$} & Wet & $0-2$ & 1.6 & & 0.8 & Formenti et al. (2001) \\
\hline & Wet & $2-10$ & 5.8 & & 2.5 & \\
\hline \multirow[t]{4}{*}{ Cuiaba (S) } & Dry & $0-2$ & 17 & 2.6 & & Echalar et al. (1998) \\
\hline & Dry & $2-10$ & 32 & & & \\
\hline & Wet & $0-2$ & 3.9 & 0.7 & & \\
\hline & Wet & $2-10$ & 11.7 & & & \\
\hline \multirow[t]{4}{*}{$\mathrm{AF}(\mathrm{F})$} & Dry & $0-2$ & 47 & 5.7 & & \\
\hline & Dry & $2-10$ & 34 & & & \\
\hline & Wet & $0-2$ & 5.5 & 0.66 & & \\
\hline & Wet & $2-10$ & 16.4 & & & \\
\hline \multirow[t]{4}{*}{$\mathrm{AF}(\mathrm{F})$} & Dry & $0-2$ & 63 & 7.7 & & Maenhaut et al. (2002) \\
\hline & Dry & $2-10$ & 37 & 1.46 & & \\
\hline & Wet & $0-2$ & 9.9 & 1.55 & & \\
\hline & Wet & $2-10$ & 15.1 & 0.38 & & \\
\hline Cuiaba (S) & All & $0-2$ & 10.5 & 2 & & Artaxo et al. (1994) \\
\hline $\mathrm{AF}(\mathrm{F})$ & All & $0-2$ & 49.9 & & & \\
\hline $\operatorname{SdN}(F)$ & All & $0-2$ & 9.87 & & & \\
\hline \multirow[t]{2}{*}{ Manaus(F) } & All & $0-2.5$ & 2.5 & 0.25 & 1.4 & This work \\
\hline & All & $2.5-10$ & 6.4 & 0.05 & 4.7 & \\
\hline
\end{tabular}


misleading. EBC data here reported correspond to EBC concentrations obtained by optical measurements; thus EC values (i.e. thermal-optical measurements) are not included in Table 2. Only a few campaigns reported EBC measurements in pasture and savanna areas. In the forest sites EBC concentration was higher during the dry season compared to the wet season, as expected due to the seasonality of biomass burning. The fine particle EBC concentration measured in this study was close to the lower bound of forest site range: $0.5-7.7 \mu \mathrm{g} \mathrm{m}^{-3}$ during the dry season, and $0.1-1.5 \mu \mathrm{g} \mathrm{m}^{-3}$ during the wet season; the contribution of biomass burning during this study was smaller compared to campaigns performed during previous years and in different sites. These results agree with the reduction of $30 \%$ of deforestation rate observed in 2008 compared to the previous decade (INPE http://www.inpe.br).

OC measurements in Amazonia are available only for a small number of sites and seasons. During the dry season $\mathrm{OC}$ at the pasture site of Fazenda Nossa Senhora Aparecida (FNSA) was one order of magnitude larger than the concentration observed at the Balbina forest site. Similarly, the EBC concentration was 10 times larger. Most likely biomass burning was responsible for the different EBC and OC concentration, as well. OC concentration during this study was larger than the values measured in Balbina, especially during the dry season, although the OC to mass ratio was quite similar.

Aerosol mass concentrations and carbonaceous species concentrations measured during this study show that the site was representative of the Amazon forest regional background.

\subsection{Carbonaceous aerosol sources}

Total carbon (TC), calculated as the sum of OC and EC, composed the largest fraction of both fine and coarse aerosol mass. To identify TC sources PMF analysis was applied to EC/OC thermograms. The term thermogram indicates the flame ionization detector (FID) signal recorded versus time by the thermal-optical analyzer. Thermograms of fine and coarse samples were analyzed separately as we expected different carbon sources for different particle size modes. The PMF analysis describes fine and coarse TC as the sum of independent factors; each factor was interpreted as a carbon source and the factor profile was the thermogram of the corresponding source.

Fine carbon aerosol factors are reported in Fig. 6a. Factor 1 had a large contribution of carbon species that evolved at low and medium temperature in He environment; $50 \%$ of factor 1 carbon mass evolved below $300^{\circ} \mathrm{C}$. Factor 2 showed a large carbon mass fraction that evolved in oxidizing environment, i.e. EC and/or pyrolytic carbon produced during the first heating steps in He. Factor 3 was the most volatile factor and $63 \%$ of its carbon mass evolved at $200^{\circ} \mathrm{C}$ in $\mathrm{He}$.

PMF factors from the analysis of coarse aerosol particles are displayed in Fig. 6b. More than $80 \%$ of carbon mass

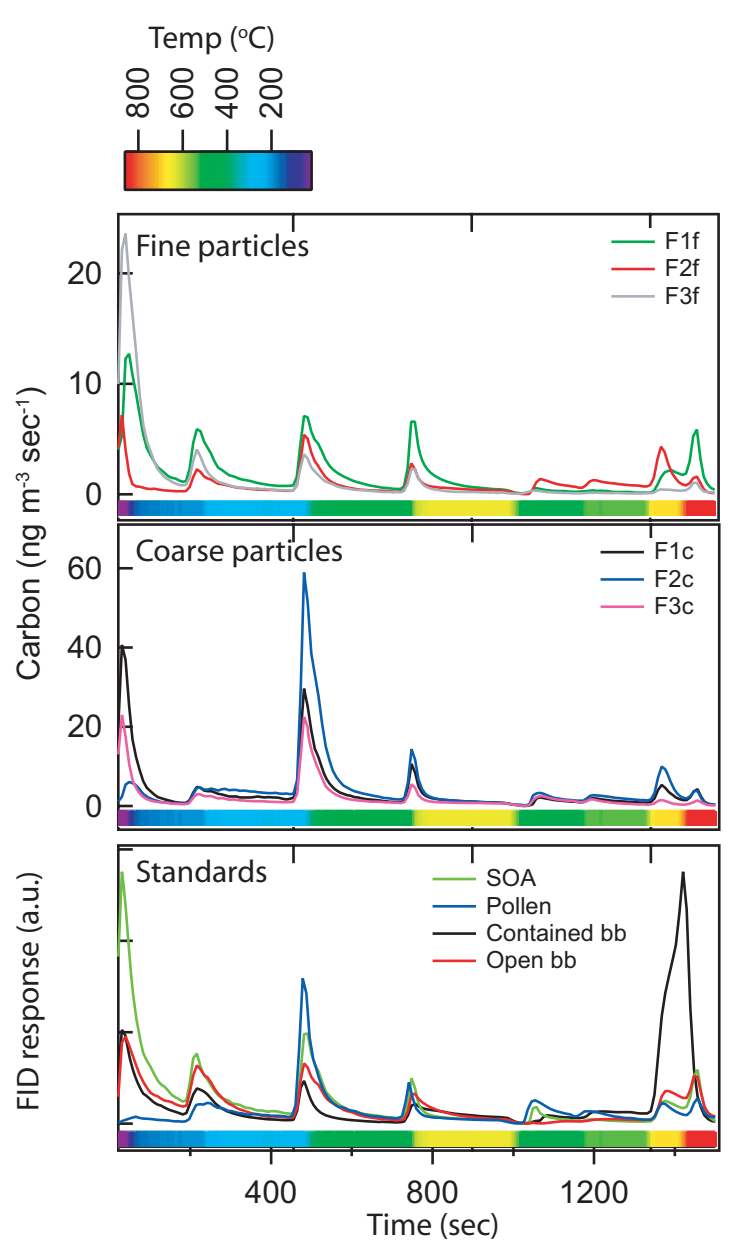

Fig. 6. PMF profiles of fine (a) and coarse (b) total carbon factors, and standard thermograms (c).

evolved in He environment for all the three factors. Factor 1 and factor 3 were characterized by large peaks at 200 and $450^{\circ} \mathrm{C}$, but factor 1 had a slightly larger contribution of carbon mass that evolved in oxidizing conditions, at higher temperature. Factor 2 profile was characterized by a large peak at $450{ }^{\circ} \mathrm{C}$ that corresponded to $50 \%$ of the carbon mass.

To identify carbon sources from PMF profiles, we analyzed a set of standards representative of the Amazon aerosols. This set includes biogenic and anthropogenic SOA from oxidation of VOCs in chamber experiments (Cavalli et al., 2010), open and contained biomass burning aerosols (Colombi et al., 2010), and PBAP (fungal spores, fungi, and pollens). Several SOA precursors were used and a variety of oxidation conditions employed, as reported in Table 3. SOA are obtained by oxidation of alpha-pinene (12 Torr) or toluene (650 Torr) with the addition of $\mathrm{CH}_{3} \mathrm{ONO}$ (24 Torr) to generate $\mathrm{OH}$ radicals and $\mathrm{NO}$ (12 Torr). Photo-oxidation period was $1 \mathrm{~h}$ (experiments a in Table 3 ) and $5 \mathrm{~h}$ (experiments b). Biomass burning standards include aerosol produced by contained combustion of pine wood, open combustion of 
Table 3. List of aerosol standards used to identify PMF profiles and their similarities with PMF factors defined by $r^{2}$.

\begin{tabular}{llll}
\hline $\begin{array}{l}\text { Standards } \\
\text { Type }\end{array}$ & Details & $\begin{array}{l}\text { Similarities } \\
\text { Factor }\end{array}$ & $r^{2}$ \\
\hline SOA & SOAbio-a & Fine F1 & 0.72 \\
& SOAbio-b & Fine F1 & 0.73 \\
& SOAanth-a & Fine F1 & 0.68 \\
& SOAanth-b & Fine F1 & 0.76 \\
& SOAbio+anth-a & Fine F1 & 0.77 \\
& SOAbio+anth-b & Fine F1 & 0.81 \\
\hline Biomass burning & Contained combustion & Fine F2 & 0.48 \\
& Open combustion branches & Fine F2 & 0.41 \\
& flaming & & \\
& Open combustion branches & Fine F2 & 0.53 \\
& smoldering & Fine F2 & 0.45 \\
& Open combustion leaves & & \\
\hline Fungal spores & smoldering & Coarse F3 & 0.48 \\
& Lycoperdon & Coarse F3 & 0.83 \\
& Panaeolus & Coarse F3 & 0.85 \\
\hline Pollens & Panaeolus & Coarse F3 & 0.94 \\
\hline Fungi & Poplar pollens & Coarse F3 & 0.91 \\
\hline
\end{tabular}

grapevine branches in flaming and smoldering conditions, and open burning of leaves of chestnut and oak (Colombi et al., 2010). Single chemical compounds (i.e. fulvic acids and levoglucosan) were analyzed, as well, but their similarities with PMF profiles were poor. Thermograms representative of each group are reported in Fig. 6c.

The comparison among PMF profiles and standard thermograms shows that the volatility of factor 1 resembles that of SOA from smog-chamber experiments. The lack of unique tracers for SOA and the expected differences between ambient and smog-chamber SOA do not allowed a more robust attribution. Nevertheless, the AMS measurements performed at the same site during the wet season confirmed that SOA dominated organic mass of submicron particles (Pöschl et al., 2010). The correlation coefficient $\left(r^{2}\right)$ of factor 1 with SOA thermograms ranged between 0.72 and 0.81 , corresponding to significance level higher than $99.9 \%$. The average carbon concentration from SOA was $0.5 \pm 0.3 \mu \mathrm{g} \mathrm{m}^{-3}$, with similar values during wet and dry season.

Fine factor 2 was assigned to biomass burning because of the similarity with combustion aerosol thermograms and the correlation with biomass burning tracers. A large fraction of carbon from factor 2 evolved in oxidizing environment, as for biomass burning aerosol thermograms. The correlation between factor 2 profile and combustion standard thermograms varied between 0.41 and 0.53 (significance level higher than $99.9 \%$ ). The lower $r^{2}$ values are likely due to aging processing that affected ambient but not standard aerosols. Still it is interesting to note that thermograms from contained combustions were characterized by a larger fraction of car- bon that evolved in oxidizing condition, compared with the open combustion. Moreover, carbon from factor 2 correlated with EBC, a tracer of biomass burning $\left(r^{2}=0.81\right.$, significance level $99.9 \%$ ), and correlated with the number of fires affecting the site during the sampling periods $\left(r^{2}=0.47\right.$, 11 data points, significance level $97.5 \%$ ). The number of fires was calculated as the number of hot spots detected by MODIS (Moderate Resolution Imaging Spectroradiometer, Terra thermal anomalies/fire daily L3 global $1 \mathrm{~km}$ SIN grid V005) that were intercepted by the back-trajectories reaching the sampling site (10-day back-trajectories from Hybrid Single-Particle Lagrangian Integrated Trajectory model calculated every $6 \mathrm{~h}$ ). The spatial resolution of grid used to overlap back-trajectories and fire spots was $1^{\circ} \times 1^{\circ}$ and only fires that were less than $500 \mathrm{~km}$ distant were taken into account.

Subramanian et al. (2007) investigated the thermal properties of brown carbon produced during wood smoldering. The corresponding thermograms were characterized by a large peak below $300^{\circ} \mathrm{C}$ in $\mathrm{He}$ and a couple of smaller peaks around $700^{\circ} \mathrm{C}$ in oxidizing environment. The thermograms were similar to the profile of fine factor 3 , suggesting a possible link between the volatile species represented by fine factor 3 and smoldering emissions.

Over the entire campaign $44 \%$ of fine carbon mass was due to biomass burning, $43 \%$ to SOA, and $13 \%$ to volatile species. The carbon fraction represented by biomass burning and SOA were $35 \%$ and $49 \%$ during the wet season, and $71 \%$ and $25 \%$ during the dry season, respectively. Emissions from biomass burning can lead to the formation of SOA (quantified by factor 1), as well as to the presence of volatile species (quantified by factor 3); thus the biomass burning PMF factor represents a lower estimate of the total biomass burning contribution to the fine carbon content.

Previous measurements in the Amazon forest identified aerosol sources; since these studies apportioned aerosol mass rather than carbon mass, a straightforward comparison could not be performed, instead the relative contribution of sources will be compared. During the wet season Pauliquevis et al. (2007) reported that at Balbina the contribution of biomass burning was slightly smaller than biogenic aerosol (37\% and $45 \%$, respectively), in agreement with this study. AMS measurements performed during the wet season in 2008 (Chen et al., 2009) indicated that SOA dominated the submicron organic aerosol during in-basin influence periods.

Literature studies indicated that PBAP composed the largest fraction of the coarse mass (Artaxo et al., 1990; Echalar et al., 1998; Martin et al., 2010); pollen and fungi (mainly yeast) were the PBAP characterized by the largest particle number concentration (Graham et al., 2003). A few coarse aerosol particles collecting in this study were investigated with scanning electron microscopy (SEM). Figure 7 shows biogenic particles visually recognized as pollens and characterized by the presence of biogenic elements (sulfur, potassium, and phosphorous). BPAP have been 

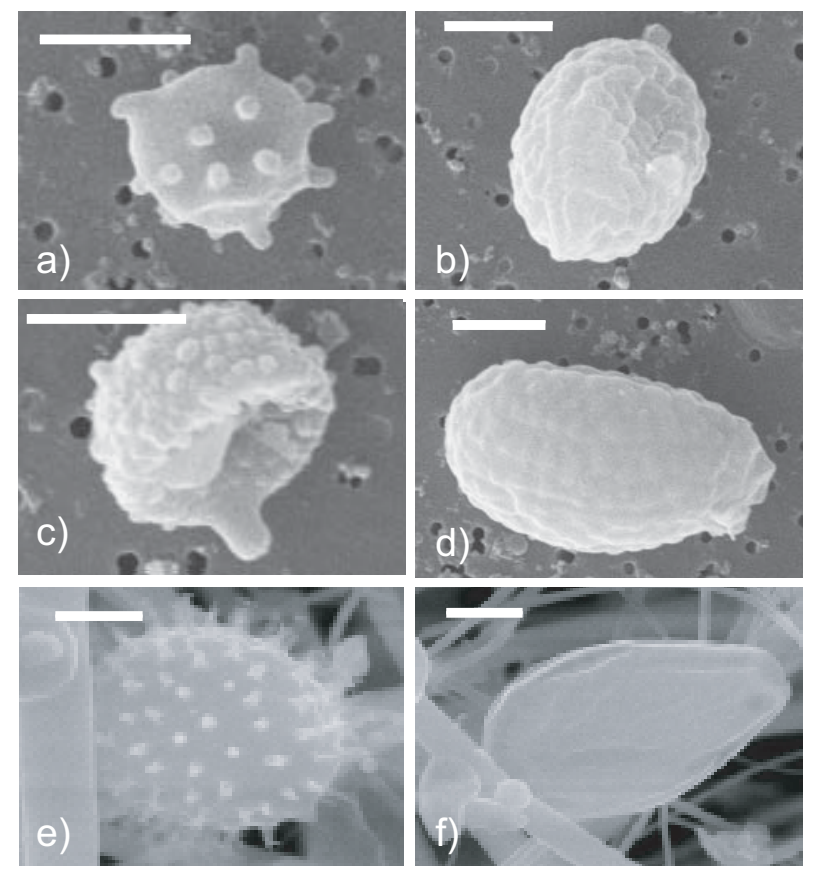

Fig. 7. Scanning electron micrographs of PBAP collected during the wet season on polycarbonate (a-d) and quartz (e-f) substrate; the white line corresponds to $2 \mu \mathrm{m}$. SEM analysis was performed with a Leica (Cambridge) Stereoscan 420 Scanning Electron Microscope (SEM), equipped with a $\mathrm{Si}(\mathrm{Li})$ energy dispersive $\mathrm{x}$-ray analyzer (EDX) with a Be window. Accelerating voltage: $25 \mathrm{kV}$, beam current: $700 \mathrm{pA}$.

investigated by thermal-optical analysis; pollens, yeasts, and fungal spores thermograms showed very similar features (Fig. 6c).

Coarse factor 2 was assigned to biogenic particles because its profile strongly correlated with that of PBAP $\left(r^{2}=0.68-\right.$ $0.94)$. Factor 2 composed $51 \%$ of coarse carbon during the wet season and $26 \%$ during the dry season (about $40 \%$ of $\mathrm{PM}_{10}$ TC). Since we were not able to assign the remaining two coarse factor profiles to specific sources, we do not exclude that PBAP might represent a larger fraction of coarse carbon, as biogenic particle types not included in the set of standards here reported might have different thermal properties.

The concentration of PBAP from factor 2 averaged $2.4 \pm 1.6 \mu \mathrm{g} \mathrm{m}^{-3}$, with higher values during the wet season, up to $7 \mu \mathrm{g} \mathrm{m}^{-3}$. These values agree with the global model (Geos-CHEM) simulation of PBAP in the Amazon basin (Heald and Spracklen, 2009). The simulations, based on leaf area index and water vapor concentrations, are optimized using mannitol concentration measurements, a tracer of fungal spore emissions. The agreement confirms that PBAP contribute significantly to the global carbon budget, especially in forest areas.
Previous studies quantified PBAP by counting and assuming a known mass or carbon mass content per each particle (Winiwarter et al., 2009; Heald and Spracklen, 2009; Huffman et al., 2010). Unfortunately the PBAP carbon content has a large variability, depending on the particle type (i.e. fungi and spores) and the species within each type (i.e. different fungi species) (Bauer et al., 2002, 2008; Elbert et al., 2007). At our best knowledge, this work is the first attempt to measure directly the contribution of PBAP to aerosol TC.

\subsection{Evaluation of carbonaceous sources in the model}

The comparison with previous studies performed in forest, pasture and savanna areas proved that Manaus is a regional background site, thus the aerosol species concentrations can be discussed in the light of global model results. The comparison of experimental results with model simulations will allow us

1. to understand to ability of the model in describing the regional background in the South America forest area, and

2. to evaluate the impact of aerosol sources in this region.

Monthly average concentration of EC and OC are sampled from TM5 model output at the $1^{\circ} \times 1^{\circ}$ resolution cell where the sampling site is located, and compared with monthly averages of fine aerosol concentrations (Fig. 8). The comparison has a monthly time resolution because the ECMWF data used in the model refer to a different meteorological year; the use of a higher time resolution would be inaccurate. Since the model represents the accumulation mode, measured coarse particles were discarded for the comparison.

EC was modeled correctly during the wet season but overestimated during the dry season of about 30 to $60 \%$. The peak of model values during the dry season corresponded to a peak of biomass burning inventory emissions. The inventory used to simulate biomass burning was constructed from the climatological data (GFED) of the years 1997-2001 (Van Der Werf et al., 2004). Nevertheless, the fire count data reported by the Brazilian National Institute for Space Research (INPE http://www.inpe.br) indicated a marked decrease of forest fires in Brazil during the last decade. The number of fires observed during 2008 were $30 \%$ fewer compared to 2001 and about $35 \%$ fewer compared to 1999 . Since fewer fires were initiated during the EUCAARI campaign period, GFED inventories for EC overestimated the burning emissions and the model overestimated the concentrations of EC.

TM5 model overestimated OC both during the dry and the wet season by $60-80 \%$. Although the overestimation of biomass burning inventory for 2008 might explain part of the discrepancy during the dry season, it does not justify the difference observed during the wet period. During the wet season biomass burning and SOA explained $80 \%$ of fine carbon mass, and since EC was well modeled during the wet 


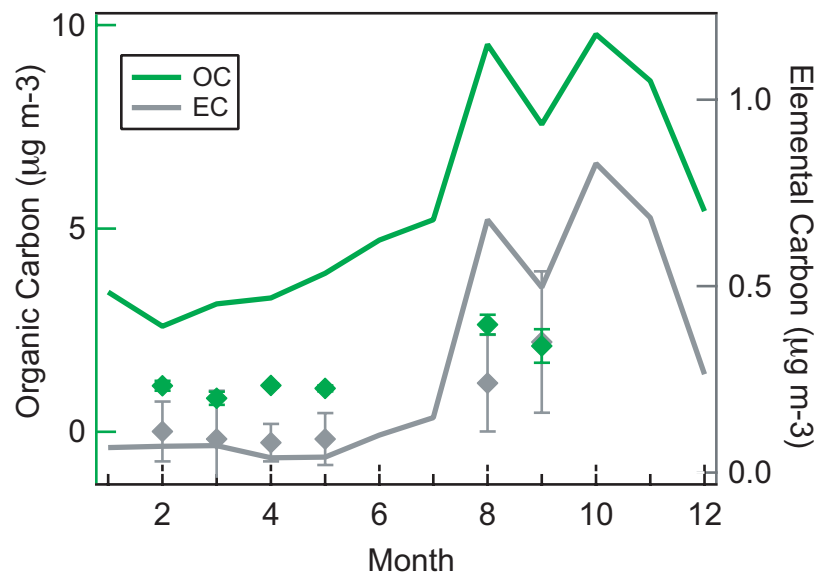

Fig. 8. Monthly average comparison of TM5 model output (lines) and observations (markers) for organic carbon OC on the left axis (green) and elemental carbon EC on the right axis (gray). The error bars correspond to \pm one standard deviation.

season, we excluded problems in modeling biomass burning; more likely SOA was responsible for the difference between modeled and measured OC values. The excess OC during the wet period, defined as the difference between modeled and measured OC, correlated with SOA carbon concentration $\left(r^{2}=0.74\right)$. The correlation indicates that for higher SOA concentration we had higher discrepancy between model and observations.

The overestimation of SOA in forest areas goes in a different direction relative to what happens in urban areas, where global models tend to underestimate SOA production (Kanakidou et al., 2005).

\section{Conclusions}

The EUCAARI project supported a scientific effort to better characterize the chemical properties of atmospheric aerosol in developing countries facing a rapid economic growth. As part of this effort, the composition of fine and coarse aerosols was investigated in a Brazilian forest site from February till September 2008.

This paper illustrates the first long term measurements performed in an Amazon forest undisturbed site since 2001 (Martin et al., 2010), characterizing the chemical composition of fine and coarse aerosol mass during both dry and wet season. This new set of data is extremely useful to show how the Amazon fire reduction of the last decade affected the regional background aerosol composition and to point out the need of up-to-date biomass burning inventories.

The average fine and coarse aerosol mass concentration was $2.4 \mu \mathrm{g} \mathrm{m}^{-3}$ and $7.9 \mu \mathrm{g} \mathrm{m}^{-3}$ during the wet season, and $4.2 \mu \mathrm{g} \mathrm{m}^{-3}$ and $7.6 \mu \mathrm{g} \mathrm{m}^{-3}$ during the dry season, respectively. Fine and coarse masses were dominated by carbonaceous particles. The average OC to aerosol mass ratio was
0.4 and 0.6 in fine and coarse aerosol mode, respectively, while EC was present almost exclusively in the fine particles, with higher concentration during the dry season: EC composed 4 and $10 \%$ of fine mass during wet and dry period, respectively. The similarity of aerosol mass concentration and chemical composition with data reported by previous studies indicates that Manaus is a representative regional background forest site, and thus underpinned the importance of carbonaceous aerosol on the global scale.

PMF analysis of thermograms was applied for the first time to the characterization of carbonaceous aerosol sources in ambient air. Although this approach can be used only to differentiate carbon classes that showed clearly different thermal behaviors, it allowed us to give an estimate of biomass burning and SOA contributions to fine carbon mass and of PBAP to coarse carbon mass. Biomass burning composed $44 \%$ and SOA composed $43 \%$ of fine carbon mass. The relative contribution of the two sources agreed with the results of previous studies in the Amazon basin. PMF analysis of coarse aerosol carbon identified one factor with a profile similar to that of PBAP and the average carbon concentration assigned to this factor was $2.4 \mu \mathrm{g} \mathrm{m}^{-3}$, with higher values during the wet season. PBAP represented $46 \%$ of coarse carbon mass. Traditional techniques quantify primary biogenic aerosol particles by measuring their number concentration and assuming a known density (Pöschl et al., 2010). Otherwise carbon content of PBAP is quantified by means of tracer method (Bauer et al., 2002) assuming a known and constant tracer emission factor. The PMF analysis of thermograms is a valuable tool to quantify directly the OC associate to PBAP without assumptions about the particles properties.

The identification of carbonaceous particle sources is mandatory to better understand and predict the effect of aerosol on climate, in fact it allowed us to point out the inaccuracies of aerosol global model simulations in South America. The comparison of aerosol composition with TM5 global model underlined the need of accurate and up-to-date emission inventories for biomass burning and a better constrain for SOA. The observations also showed the relevance of PBAP on the global scale carbon budget.

Acknowledgements. We acknowledge Lívia Oliveira, Ana Lucia Loureiro, Alcides C. Ribeiro and Fernando Morais, for helping with the sampling site management and the sample collection. We thank INPA (Instituto Nacional de Pesquisas da Amazonia) for logistical and operational support. This work is supported by the European Commission on the IP EUCAARI (036833-2) project. Paulo Artaxo acknowledges FAPESP and CNPq for funding his component of this research.

Edited by: E. Vignati 


\section{References}

Ahlm, L., Nilsson, E. D., Krejci, R., Mårtensson, E. M., Vogt, M., and Artaxo, P.: Aerosol number fluxes over the Amazon rain forest during the wet season, Atmos. Chem. Phys., 9, 9381-9400, doi:10.5194/acp-9-9381-2009, 2009.

Alexander, M. L., Crozier, P. A., and Anderson, J. R.: Brown carbon spheres in East Asia outflow and their optical properties, Science, 321, 833-836, 2008.

Andreae, M.: Soot carbon and excess fine potassium: Long-range transport of combustion-derived aerosols, Science, 220, 11481151, 1983.

Andreae, M. and Crutzen, P.: Atmospheric aerosols: Biogeochemical sources and role in atmospheric chemistry, Science, 276, 1052-1058, 1997.

Andreae, M. O. and Gelencsér, A.: Black carbon or brown carbon? The nature of light-absorbing carbonaceous aerosols, Atmos. Chem. Phys., 6, 3131-3148, doi:10.5194/acp-6-3131-2006, 2006.

Andreae, M., Andreae, T., Ferek, R., and Raemdonck, H.: Longrange transport of soot carbon in the marine atmosphere, Sci. Total Environ., 36, 73-80, 1984.

Andreae, M., Artaxo, P., Fischer, H., Freitas, S., Grégoire, J.M., Hansel, A., Hoor, P., Kormann, R., Krejci, R., Lange, L., Lelieveld, J., Lindinger, W., Longo, K., Peters, W., De Reus, M., Scheeren, B., Silva Dias, M., Ström, J., Van Velthoven, P., and Williams, J.: Transport of biomass burning smoke to the upper troposphere by deep convection in the equatorial region, Geophys. Res. Lett., 28, 951-954, 2001.

Ansmann, A., Baars, H., Tesche, M., ller, D. M., Althausen, D., Engelmann, R., Pauliquevis, T., and Artaxo, P.: Dust and smoke transport from Africa to South America: Lidar profiling over Cape Verde and the Amazon rainforest, Geophys. Res. Lett., 36, L11802, doi:10.1029/2009GL037923, 2009.

Artaxo, P., Maenhaut, W., Storms, H., and Van Grieken, R.: Aerosol characteristics and sources for the Amazon Basin during the wet season, J. Geophys. Res., 95, 16971-16985, 1990.

Artaxo, P., Gerab, F., Yamasoe, M., and Martins, J.: Fine mode aerosol composition at three long-term atmospheric monitoring sites in the Amazon Basin, J. Geophys. Res., 99, 22857-22868, 1994.

Artaxo, P., Martins, J., Yamasoe, M., Procópio, A., Pauliquevis, T., Andreae, M., Guyon, P., Gatti, L., and Leal, A.: Physical and chemical properties of aerosols in the wet and dry seasons in Rondônia, Amazonia, J. Geophys. Res., 107, 49-1-49-14, 2002.

Bauer, H., Kasper-Giebl, A., Zibuschka, F., Hitzenberger, R., Kraus, G., and Puxbaum, H.: Determination of the carbon content of airborne fungal spores, Anal. Chem., 74, 91-95, 2002.

Bauer, H., Schueller, E., Weinke, G., Berger, A., Hitzenberger, R., and Marr, I., and Puxbaum, H.: Significant contributions of fungal spores to the organic carbon and to the aerosol mass balance of the urban atmospheric aerosol, Atmos. Environ., 42, 55425549, 2008.

Birch, M. E. and Cary, R. A.: Elemental carbon-based method for monitoring occupational exposures to particulate diesel exhaust, Aerosol Sci. Technol., 25, 221-241, 1996.

Bond, T., Venkataraman, C., and Masera, O.: Global atmospheric impacts of residential fuels, Energy for Sustainable Development, 8, 20-32, 2004.

Bond, T. C. and Bergstrom, R. W.: Light absorption by carbona- ceous particles: An investigative review, Aerosol Sci. Technol., 40, 1-41, 2006.

Cavalli, F., Viana, M., Yttri, K. E., Genberg, J., and Putaud, J.P.: Toward a standardised thermal-optical protocol for measuring atmospheric organic and elemental carbon: the EUSAAR protocol, Atmos. Meas. Tech., 3, 79-89, doi:10.5194/amt-3-79-2010, 2010.

Chen, Q., Farmer, D., Schneider, J., Zorn, S., Heald, C., Karl, T., Guenther, A., Allan, J., Robinson, N., Coe, H., Kimmel, J., Pauliquevis, T., Borrmann, S., Poschl, U., Andreae, M., Artaxo, P., Jimenez, J., and Martin, S.: Mass spectral characterization of submicron biogenic organic particles in the Amazon Basin, Geophys. Res. Lett., 36, L20806, doi:10.1029/2009GL039880, 2009.

Claeys, M., Kourtchev, I., Pashynska, V., Vas, G., Vermeylen, R., Wang, W., Cafmeyer, J., Chi, X., Artaxo, P., Andreae, M. O., and Maenhaut, W.: Polar organic marker compounds in atmospheric aerosols during the LBA-SMOCC 2002 biomass burning experiment in Rondnia, Brazil: sources and source processes, time series, diel variations and size distributions, Atmos. Chem. Phys., 10, 9319-9331, doi:10.5194/acp-10-9319-2010, 2010.

Colombi, C., Gianelle, V., Belis, C. A., and Larsen, B. R.: Determination of local source profile for soil dust, brake dust, and biomass burning sources, Chemical Engineering Transactions, 22, 233-238, doi:10.3303/CET1022038, 2010.

Dana, M. T. and Hales, J. M.: Statistical aspects of the washout of polydisperse aerosols, Atmos. Environ., 10, 45-50, 1976.

de Meij, A., Krol, M., Dentener, F., Vignati, E., Cuvelier, C., and Thunis, P.: The sensitivity of aerosol in Europe to two different emission inventories and temporal distribution of emissions, Atmos. Chem. Phys., 6, 4287-4309, doi:10.5194/acp-6-4287-2006, 2006.

Decesari, S., Fuzzi, S., Facchini, M. C., Mircea, M., Emblico, L., Cavalli, F., Maenhaut, W., Chi, X., Schkolnik, G., Falkovich, A., Rudich, Y., Claeys, M., Pashynska, V., Vas, G., Kourtchev, I., Vermeylen, R., Hoffer, A., Andreae, M. O., Tagliavini, E., Moretti, F., and Artaxo, P.: Characterization of the organic composition of aerosols from Rondnia, Brazil, during the LBASMOCC 2002 experiment and its representation through model compounds, Atmos. Chem. Phys., 6, 375-402, doi:10.5194/acp6-375-2006, 2006.

Dentener, F., Kinne, S., Bond, T., Boucher, O., Cofala, J., Generoso, S., Ginoux, P., Gong, S., Hoelzemann, J. J., Ito, A., Marelli, L., Penner, J. E., Putaud, J.-P., Textor, C., Schulz, M., van der Werf, G. R., and Wilson, J.: Emissions of primary aerosol and precursor gases in the years 2000 and 1750 prescribed data-sets for AeroCom, Atmos. Chem. Phys., 6, 4321-4344, doi:10.5194/acp6-4321-2006, 2006.

Echalar, F., Artaxo, P., Martins, J., Yamasoe, M., Gerab, F., Maenhaut, W., and Holben, B.: Long-term monitoring of atmospheric aerosols in the amazon basin: Source identification and apportionment, J. Geophys. Res., 103, 31849-31864, 1998.

Elbert, W., Taylor, P. E., Andreae, M. O., and Pöschl, U.: Contribution of fungi to primary biogenic aerosols in the atmosphere: wet and dry discharged spores, carbohydrates, and inorganic ions, Atmos. Chem. Phys., 7, 4569-4588, doi:10.5194/acp-7-4569-2007, 2007.

Falkovich, A. H., Graber, E. R., Schkolnik, G., Rudich, Y., Maenhaut, W., and Artaxo, P.: Low molecular weight organic acids 
in aerosol particles from Rondnia, Brazil, during the biomassburning, transition and wet periods, Atmos. Chem. Phys., 5, 781797, doi:10.5194/acp-5-781-2005, 2005.

Feng, Y. and Penner, J.: Global modeling of nitrate and ammonium: Interaction of aerosols and tropospheric chemistry, J. Geophys. Res., 112, D01304, doi:10.1029/2005JD006404, 2007.

Formenti, P., Andreae, M. O., Lange, L., Roberts, G., Cafmeyer, J., Rajta, I., Maenhaut, W., Holben, B., Artaxo, P., and Lelieveld, J.: Saharan dust in Brazil and Suriname during the Large-ScaleBiosphere-Atmosphere Experiment in Amazonia (LBA)- Cooperative LBA Regional Experiment (CLAIRE) in March 1998, J. Geophys. Res., 106, 14919-14934, 2001.

Fuzzi, S., Andreae, M. O., Huebert, B. J., Kulmala, M., Bond, T. C., Boy, M., Doherty, S. J., Guenther, A., Kanakidou, M., Kawamura, K., Kerminen, V.-M., Lohmann, U., Russell, L. M., and Pöschl, U.: Critical assessment of the current state of scientific knowledge, terminology, and research needs concerning the role of organic aerosols in the atmosphere, climate, and global change, Atmos. Chem. Phys., 6, 2017-2038, doi:10.5194/acp-62017-2006, 2006.

Ganzeveld, L. and Lelieveld, J.: Dry deposition parameterization in a chemistry general circulation model and its influence on the distribution of reactive trace gases, J. Geophys. Res, 100, 20999_ 21012, 1995.

Gery, M. W., Whitten, G. Z., and Killus, J. P.: Development and testing of the CBM-IV for urban and regional modelling, EPA600/3-88-012, Tech. rep., US EPA, Research Triangle Park NC, 1989a.

Gery, M. W., Whitten, G. Z., Killus, J. P., and Dodge, M. C.: A photochemical kinetics mechanism for urban and regional scale computer modeling, J. Geophys. Res, 94D, 12925-12956, 1989 b.

Gilardoni, S., Liu, S., Takahama, S., Russell, L. M., Allan, J. D., Steinbrecher, R., Jimenez, J. L., De Carlo, P. F., Dunlea, E. J., and Baumgardner, D.: Characterization of organic ambient aerosol during MIRAGE 2006 on three platforms, Atmos. Chem. Phys., 9, 5417-5432, doi:10.5194/acp-9-5417-2009, 2009.

Goldstein, A. and Galbally, I.: Known and unexplored organic constituents in the earth's atmosphere, Environ. Sci. Technol., 41, 1514-1521, 2007.

Graham, B., Guyon, P., Maenhaut, W., Taylor, P., Ebert, M., Matthias-Maser, S., Mayol-Bracero, O., Godoi, R., Artaxo, P., Meixner, F., Lima Moura, M., Eça D’Almeida Rocha, C., Van Grieken, R., Glovsky, M., Flagan, R., and Andreae, M.: Composition and diurnal variability of the natural Amazonian aerosol, J. Geophys. Res., 108, AAC 5-1-AAC 5-16, 2003.

Grosjean, D., Williams, E. L., Grosjean, E., and Novakov, T.: Evolved gas analysis of secondary organic aerosol, Aerosol Sci. Technol., 21, 306-324, 1994.

Guelle, W., Balkanski, Y. J., Schulz, M., Dulac, F., and Monfray, P.: Wet deposition in a global size-dependent aerosol transport model. 1. Comparison of a 1 year $210 \mathrm{~Pb}$ simulation with ground measurements, J. Geophys. Res, 103, 11429-11445, 1998.

Gunthe, S. S., King, S. M., Rose, D., Chen, Q., Roldin, P., Farmer, D. K., Jimenez, J. L., Artaxo, P., Andreae, M. O., Martin, S. T., and Pöschl, U.: Cloud condensation nuclei in pristine tropical rainforest air of Amazonia: size-resolved measurements and modeling of atmospheric aerosol composition and CCN activity, Atmos. Chem. Phys., 9, 7551-7575, doi:10.5194/acp-9-7551-
2009, 2009.

Guyon, P., Graham, B., Roberts, G., Mayol-Bracero, O., Maenhaut, W., Artaxo, P., and Andreae, M.: In-canopy gradients, composition, sources, and optical properties of aerosol over the Amazon forest, J. Geophys. Res., 108, AAC 9-1-AAC 9-16, 2003.

Guyon, P., Graham, B., Roberts, G., Mayol-Bracero, O., Maenhaut, W., Artaxo, P., and Andreae, M.: Sources of optically active aerosol particles over the Amazon forest, Atmos. Environ., 38, 1039-1051, 2004.

Heald, C. and Spracklen, D.: Atmospheric budget of primary biological aerosol particles from fungal spores, Geophys. Res. Lett., 36, L09806, doi:10.1029/2009GL037493, 2009.

Hertel, O., Berkowicz, R., and Christensen, J.: Test of two numerical schemes for use in atmospheric transport-chemistry models., Atmos. Environ., 16, 2591-2611, 1993.

Houweling, S., Dentener, F., and Lelieveld, J.: The impact of nonmethane hydrocarbon compounds on tropospheric photochemistry, J. Geophys. Res, 103, 10673-10696, 1998.

Huffman, J. A., Treutlein, B., and Pöschl, U.: Fluorescent biological aerosol particle concentrations and size distributions measured with an Ultraviolet Aerodynamic Particle Sizer (UVAPS) in Central Europe, Atmos. Chem. Phys., 10, 3215-3233, doi:10.5194/acp-10-3215-2010, 2010.

Hwang, H. and Ro, C.-U.: Direct observation of nitrate and sulfate formations from mineral dust and sea-salts using low- $Z$ particle electron probe X-ray microanalysis, Atmos. Environ., 40, 38693880, 2006.

IPCC: ICPP: Climate Change 2001: the scientific bases, Cambridge University Press, New York, 2001.

IPCC: Fourth Assessment Record: Climate change 2007, Cambridge University Press, New York, 2007.

Jeuken, A., Veefkind, J. P., Dentener, F., Metzger, S., and Robles Gonzalez, C.: Simulation of the aerosol optical depth over Europe for August 1997 and a comparison with observations, J. Geophys. Res, 106, 28295-28311, 2001.

Kanakidou, M., Seinfeld, J. H., Pandis, S. N., Barnes, I., Dentener, F. J., Facchini, M. C., Van Dingenen, R., Ervens, B., Nenes, A., Nielsen, C. J., Swietlicki, E., Putaud, J. P., Balkanski, Y., Fuzzi, S., Horth, J., Moortgat, G. K., Winterhalter, R., Myhre, C. E. L., Tsigaridis, K., Vignati, E., Stephanou, E. G., and Wilson, J.: Organic aerosol and global climate modelling: a review, Atmos. Chem. Phys., 5, 1053-1123, doi:10.5194/acp-5-1053-2005, 2005.

Kirchstetter, T. W., Novakov, T., and Hobbs, P. V.: Evidence that the spectral dependence of light absorption by aerosols is affected by organic carbon, J. Geophys. Res, 109, 21201-21212, 2004.

Krol, M., Houweling, S., Bregman, B., van den Broek, M., Segers, A., van Velthoven, P., Peters, W., Dentener, F., and Bergamaschi, P.: The two-way nested global chemistry-transport zoom model TM5: algorithm and applications, Atmos. Chem. Phys., 5, 417432, doi:10.5194/acp-5-417-2005, 2005.

Kulmala, M., Asmi, A., Lappalainen, H. K., Carslaw, K. S., Pöschl, U., Baltensperger, U., Hov, Ø., Brenquier, J.-L., Pandis, S. N., Facchini, M. C., Hansson, H.-C., Wiedensohler, A., and O'Dowd, C. D.: Introduction: European Integrated Project on Aerosol Cloud Climate and Air Quality interactions (EUCAARI) - integrating aerosol research from nano to global scales, Atmos. Chem. Phys., 9, 2825-2841, doi:10.5194/acp-9-2825-2009, 2009. 
Liao, H., Seinfeld, J., Adams, P., and Mickley, L.: Global radiative forcing of coupled tropospheric ozone and aerosols in a unified general circulation model, J. Geophys. Res., 109, D16207, doi:10.1029/2003JD004456, 2004.

Lim, Y. B., Tan, Y., Perri, M. J., Seitzinger, S. P., and Turpin, B. J.: Aqueous chemistry and its role in secondary organic aerosol (SOA) formation, Atmos. Chem. Phys., 10, 1052-10539, doi:10.5194/acp-10-10521-2010, 2010.

Liousse, C., Cachier, H., and Jennings, S. G.: Optical and thermal measurements of black carbon aerosol content in different environments: Variation of the specific attenuation cross-section, sigma, Atmos. Environ., 27A, 1203-1211, 1993.

Liu, S., Takahama, S., Russell, L. M., Gilardoni, S., and Baumgardner, D.: Oxygenated organic functional groups and their sources in single and submicron organic particles in MILAGRO 2006 campaign, Atmos. Chem. Phys., 9, 6849-6863, doi:10.5194/acp9-6849-2009, 2009.

Maenhaut, W., Fernandez-Jimenez, M. T., Rajta, I., and Artaxo, P.: Two-year study of atmospheric aerosols in Alta Floresta, Brazil: Multielemental composition and source apportionment, Nucl. Instrum. Methods B, 189, 243-248, 2001.

Martin, S., Andreae, M., Artaxo, P., Baumgardner, D., Chen, Q., Goldstein, A., Guenther, A., Heald, C., Mayol-Bracero, O., McMurry, P., Pauliquevis, T., Poschl, U., Prather, K. A., Roberts, G. C., Saleska, S. R., Silva Dias, M. A., Spracklen, D. V., Swietlicki, E., and Trebs, I.: Sources and properties of Amazonian aerosol particles, Rev. Geophys., 48, RG2002, doi:10.1029/2008RG000280, 2010.

Martins, J. V., Artaxo, P., Kaufman, Y. J., Castanho, A. D., and Remer, L. A.: Spectral absorption properties of aerosol particles from 350-2500 nm, Geophys. Res. Lett., 36, L13810, doi:10.1029/2009GL037435, 2009.

Metzger, S., Dentener, F., Krol, M., Jeuken, A., and Lelieveld, J.: Gas-aerosol partitioning: 2. Global Modeling results., J. Geophys. Res, 107, 4313, doi:10.1029/2001JD001103, 2002a.

Metzger, S., Dentener, F., Pandis, S., and Lelieveld, J.: Gas-aerosol partitioning: 1. A computationally efficient model, J. Geophys. Res, 107, 4312, doi:10.1029/2001JD001102, 2002 b.

Norris, G., Vedantham, R., Wade, K., Brown, S., Prouty, J., and Foley, C.: EPA Psotive Matrix Factorization (PMF) 3.0, fundamentals and user guide, Environmental Protection Agency EPA NC, 2008.

Pauliquevis, T., Lara, L. L., Antunes, M. L., and Artaxo, P.: Aerosol and precipitation chemistry in a remote site in Central Amazonia: the role of biogenic contribution, Atmos. Chem. Phys. Discuss., 7, 11465-11509, doi:10.5194/acpd-7-11465-2007, 2007.

Peralta, O., Baumgardner, D., and Raga, G. B.: Spectrothermography of carbonaceous particles, J. Atmos. Chem., 57, 153-169, 2007.

Petzold, A. and Schönlinner, M.: Multi-angle absorption photometry - a new method for the measurement of aerosol light absorption and atmospheric black carbon, J. Aerosol Sci., 35, 421-441, 2004.

Polissar, A. V., Paatero, P., Hopke, P. K., Malm, W. C., and Sisler, J. F.: Atmospheric aerosol over Alaska 2. Elemental composition and sources, J. Geophys. Res., 103, 19045-19057, 1998.

Pöschl, U., Martin, S. T., Sinha, B., Chen, Q., Gunthe, S., Huffman, J. A., Borrmann, S., Farmer, D., Garland, R., Helas, G., Jimenez, J. L., King, S. M., Manzi, A., Mikhailov, E., Pauliquevis, T.,
Petters, M., Prenni, A., Roldin, P., Rose, D., Schneider, J., Su, H., Zorn, S., Artaxo, P., and Andreae, M. O.: Rainforest aerosols as biogenic nuclei of clouds and precipitation in the Amazon., Science, 329, 1513-1516, 2010.

Prenni, A., Petters, M., Kreidenweis, S., Heald, C., Martin, S., Artaxo, P., Garland, R., Wollny, A., and Poschl, U.: Relative roles of biogenic emissions and saharan dust as ice nuclei in the amazon basin, Nature Geosci., 2, 402-405, 2009.

Putaud, J. P., Van Dingenen, R., and Raes, F.: Submicron aerosol mass balance at urban and semirural sites in the Milan area (Italy), J. Geophys. Res, 107, 8198, doi:10.1029/2000JD000111, 2002.

Putaud, J. P., Raes, F., Van Dingenen, R., Bruggemann, E., Facchini, M. C., Decesari, S., Fuzzi, S., Gehrig, R., Huglin, C., Laj, P., Lorbeer, G., Maenhaut, W., Mihalopoulos, N., Muller, K., Querol, X., Rodriguez, S., Schneider, J., Spindler, G., ten Brink, H., Torseth, K., and Wiedensohler, A.: A European aerosol phenomenology -2 : chemical characteristics of particulate matter at kerbside, urban, rural and background sites in Europe, Atmos. Environ., 38, 2579-2595, 2004.

Reid, J., Hobbs, P., Liousse, C., Martins, J., Weiss, R., and Eck, T.: Comparisons of techniques for measuring shortwave absorption and black carbon content of aerosols from biomass burning in Brazil, J. Geophys. Res., 103, 32031-32040, 1998.

Roberts, G., Wooster, M. J., and Lagoudakis, E.: Annual and diurnal african biomass burning temporal dynamics, Biogeosciences, 6, 849-866, doi:10.5194/bg-6-849-2009, 2009.

Russell, L. M.: Aerosol Organic-Mass-to-Organic-Carbon Ratio Measurements, Environ. Sci. Technol, 37, 2982-2987, doi:10.1021/es026123w, 2003.

Russell, L. M., Takahama, S., Liu, S., Hawkins, L. N., Covert, D. S., Quinn, P. K., and Bates, T. S.: Oxigenated fraction and mass of organic aerosol from direct emission and atmospheric processing collected on the R/V Ronald Brown during TEXAQS/GoMACCS 2006, J. Geophys. Res, 114, D00F05, doi:10.1029/2008JD011275, 2009.

Soto-García, L. L., Andreae, M. O., Andreae, T. W., Artaxo, P., Maenhaut, W., Kirchstetter, T., Novakov, T., Chow, J. C., and Mayol-Bracero, O. L.: Evaluation of the carbon content of aerosols from the burning of biomass in the Brazilian Amazon using thermal, optical and thermal-optical analysis methods, Atmos. Chem. Phys. Discuss., 10, 12859-12906, doi:10.5194/acpd-10-12859-2010, 2010.

Staudt, A., Jacob, D., Logan, J., Bachiochi, D., Krishnamurti, T., and Sachse, G.: Continental sources, transoceanic transport, and interhemispheric exchange of carbon monoxide over the Pacific, J. Geophys. Res., 106, 32571-32589, 2001.

Streets, D., Bond, T., Lee, T., and Jang, C.: On the future of carbonaceous aerosol emissions, J. Geophys. Res., 109, D24212, doi:10.1029/2004JD004902, 2004.

Subramanian, R., Roden, C. A., Boparai, P., and Bond, T. C. C.: Yellow Beads and Missing Particles: Trouble Ahead for FilterBased Absorption Measurements, Aerosol Sci. Technol., 41, 630-637, 2007.

Surratt, J. D., Chan, A. W. H., Eddingsaas, N. C., Chan, M., Loza, C. L., Kwan, A. J., Hersey, S. P., Flagan, R. C., Wennberg, P. O., and Seinfeld, J. H.: Reactive intermediates revealed in secondary organic aerosol formation from isoprene, P. Natl. Acad. Sci., 107, 6640-6645, doi:10.1073/pnas.0911114107, 2010. 
Talbot, R.: Aerosol chemistry during the wet season in central Amazonia: the influence of long-range transport, J. Geophys. Res., 95, 16955-16969, 1990.

Textor, C., Schulz, M., Guibert, S., Kinne, S., Balkanski, Y., Bauer, S., Berntsen, T., Berglen, T., Boucher, O., Chin, M., Dentener, F., Diehl, T., Easter, R., Feichter, H., Fillmore, D., Ghan, S., Ginoux, P., Gong, S., Grini, A., Hendricks, J., Horowitz, L., Huang, P., Isaksen, I., Iversen, I., Kloster, S., Koch, D., Kirkevåg, A., Kristjansson, J. E., Krol, M., Lauer, A., Lamarque, J. F., Liu, X., Montanaro, V., Myhre, G., Penner, J., Pitari, G., Reddy, S., Seland, Ø., Stier, P., Takemura, T., and Tie, X.: Analysis and quantification of the diversities of aerosol life cycles within AeroCom, Atmos. Chem. Phys., 6, 1777-1813, doi:10.5194/acp-61777-2006, 2006.

Usher, C., Michel, A., Stec, D., and Grassian, V.: Laboratory studies of ozone uptake on processed mineral dust, Atmos. Environ., 37, 5337-5347, 2003.

Van Der Werf, G. R., Randerson, J. T., Collatz, G. J., Giglio, L., Kasibhatla, P. S., Arellano, A. F., Olsen, S. C., and Kasischke, E. S.: Continental scale partitioning of fire emissions during the 1997 to $2001 \mathrm{El}$ Nino/La Nina period, Science, 303, 73-76, 2004.
Vignati, E., Karl, M., Krol, M., Wilson, J., Stier, P., and Cavalli, F.: Sources of uncertainties in modelling black carbon at the global scale, Atmos. Chem. Phys., 10, 2595-2611, doi:10.5194/acp-102595-2010, 2010.

Winiwarter, W., Bauer, H., Caseiro, A., and Puxbaum, H.: Quantifying emissions of primary biological aerosol particle mass in Europe, Atmos. Environ., 43, 1403-1409, 2009.

Zhang, Q., Jimenez, J. L., Canagaratna, M. R., Allan, J. D., Coe, H., Ulbrich, I., Alfarra, M. R., Takami, A., Middlebrook, A. M., Sun, Y. L., Dzepina, K., Dunlea, E., Docherty, K., DeCarlo, P. F., Salcedo, D., Onasch, T., Jayne, J. T., Miyoshi, T., Shimono, A., Hatakeyama, S., Takegawa, N., Kondo, Y., Schneider, J., Drewnick, F., Borrmann, S., Weimer, S., Demerjian, K., Williams, P., Bower, K., Bahreini, R., Cottrell, L., Griffin, R. J., Rautiainen, J., Sun, J. Y., Zhang, Y. M., and Worsnop, D. R.: Ubiquity and dominance of oxygenated species in organic aerosols in anthropogenically-influenced Northern Hemisphere midlatitudes, Geophys. Res. Lett., 34, L13801, doi:10.1029/2007GL029979, 2007. 